\title{
CHARACTERIZATION OF STIRRED YOGHURT ENRICHED WITH PROBIOTICS AND BEETROOT AND ITS THERAPEUTIC POTENTIAL IN EXPERIMENTAL TYPE 2 DIABETES
}

\author{
Doha A. Mohamed ${ }^{1}$, Hoda S. El-Sayed ${ }^{2}$, Mona A. M. Abd El-Gawad², \\ Sherein S. Abdelgayed ${ }^{3}$, Ibrahim M. Hamed ${ }^{1}$, Rasha S. Mohamed ${ }^{1 凶}$ \\ ${ }^{1}$ Nutrition and Food Sciences Department, National Research Centre \\ 33 Tahrir St., 12622 Dokki, Cairo, Egypt \\ 2Dairy Department, National Research Centre, Dokki, Cairo, Egypt \\ 33 Tahrir St., 12622 Dokki, Cairo, Egypt \\ ${ }^{3}$ Pathology Department, Faculty of Veterinary Medicine, Cairo University, Egypt
}

\begin{abstract}
Background. Type-2 diabetes is the most prevalent metabolic disease, which calls for researchers to find many natural products that are effective in fighting diabetes and its complications.

Materials and methods. Stirred yoghurt samples were prepared, enriched with probiotics, and fortified with either $1 \%$ or $2 \%$ of the fine powder of beetroots. The chemical, physical, sensorial, and microbial properties of the yoghurt samples were studied over a 15-day storage period. The total phenolic compounds, flavonoids, antioxidant activity as well as the reducing power of the dried beetroot and the yoghurt samples were assessed. The prepared yoghurt samples were evaluated in type 2 diabetic rats.

Results. Fortification with beetroot led to an increase of the total phenolic compounds, antioxidant activity, and the probiotic counts in the prepared yoghurt. The intervention with the prepared yoghurt samples resulted in an increase in the number of beneficial bacteria in diabetic rats' feces, hypoglycemic effect, and suppression in the elevation of C-reactive protein (CRP) and thyroid stimulating hormone (TSH).

Conclusion. This study suggests that stirred yoghurt enriched with probiotics and fortified with beetroot have therapeutic potential for type 2 diabetes.
\end{abstract}

Keywords: probiotic, beetroot, stirred yoghurt, type 2 diabetes, high fat diet, Streptozotocin

\section{INTRODUCTION}

Type 2 diabetes mellitus is one of the metabolic diseases marked by hyperglycemia as well as disturbances in the metabolism of protein, fats, and carbohydrates (Ranjith et al., 2018). Diabetes is associated with impaired insulin secretion or insulin efficiency, in addition to unusual pancreatic cell function resulting from permanent hyperglycemia and resistance of peripheral tissue to insulin (Xu et al., 2021). It was reported that the number of diabetics currently stands at 425 million patients ( $90 \%$ of patients with type 2 diabetes) according to the International Diabetes Federation (IDF), and it is estimated that these numbers will increase to reach about 700 million patients by the year 2045 (Bommer et al., 2018). Many complications, including nephropathy, cardiovascular disease, and dyslipidemia may be associated with type 2 diabetes (Wang et al., 
2020). Additionally, it has been found that diabetes mellitus led to thyroid dysfunction (Ige et al., 2019).

It was reported that the gut microbiome differs more in the type 2 diabetic patient than the healthy population. The number of Firmicutes bacteria was found to be lower, while the number of Bacteroides and Proteobacteria was higher in the gastrointestinal tract of type 2 diabetics (Larsen et al., 2010). Probiotics, the beneficial live microorganisms, were found to be supplementary therapeutics, via modulation of the gut microbiome, for type 2 diabetes mellitus in addition to their ameliorative effect on dyslipidemia and metabolic control in diabetic patients (Kocsis et al., 2020).

Nitric oxide (NO), a key regulator of vascular homeostasis, is affected by an excess of reactive oxygen species (ROS). The lack of nitric oxide is involved in vascular dysfunction in cardiovascular disease and type 2 diabetes (Jin and Loscalzo, 2010). Thus, the supplementation with $\mathrm{NO}$ via dietary inorganic nitrate $\left(\mathrm{NO}^{-}\right)$such as green leafy vegetables and beetroot may be a beneficial therapeutic for diabetes complications (Lidder and Webb, 2013). The red root of beet plant or Beta vulgaris is not only a source of dietary nitrate but also a good source of betalains, such as betanin and isobetanin, which act as antioxidant agents owing to the electron donating ability and suppress the reactive oxygen species and its subsequent health hazards (Ninfali et al., 2017).

These reports on the beneficial effects of probiotics and beetroot inspired us to prepare functional stirred yoghurt supplemented with probiotics and powder of beetroot and to investigate the effect of this functional stirred yoghurt on diabetes complications through high-fat diet fed-streptozotocin (HFD/STZ)-treated rat model.

\section{MATERIALS AND METHODS}

\section{Raw materials and chemicals}

Fresh cow's milk was obtained from the dairy department, Cairo Univ. and was used without standardization of the fat content. Beetroot was purchased from a local market in Egypt. Chemicals and pure reagents were purchased from Sigma Chemical Companies (Sigma-Aldrich, St. Louis, MO, USA).

\section{Manufacturing of stirred yoghurt with beetroot powder}

The roots of beet plant were washed, cut into thin slices, and dried using a sundering device. Then the dried slices were grounded into fine powder. Fresh cow's milk, was heated at $72^{\circ} \mathrm{C}$ for $15 \mathrm{~s}$, then was cooled and adjusted to $42^{\circ} \mathrm{C}$. The starter cultures of yoghurt (Lactobacillus bulgaricus Lb-12 DRI-VAC and Streptococcus thermophilus $\mathrm{CH}-2$ ) were added at a $2 \%$ concentration to the milk, in addition to $2 \%$ of the probiotic bacteria Bifidobacterium lactis Bb12 and Lactobacillus acidophilus $\mathrm{CH}-2$. Then the inoculated milk was divided into three portions, the first portion served as a control, the second portion was fortified with $1 \%$ beetroot powder and the third portion was fortified with $2 \%$ beetroot powder. All samples were transferred into plastic cups and incubated at $42^{\circ} \mathrm{C}$ until complete coagulation and then cooled at $4^{\circ} \mathrm{C}$ overnight. The cups were stirred using plunder and stored at $7^{\circ} \mathrm{C}$ for 15 days.

\section{Chemical analysis of stirred yoghurt samples}

The control stirred yoghurt and the stirred yoghurt fortified with red beetroot were analyzed for total solids, fat, total nitrogen, and ash contents. Carbohydrate content was calculated by difference. Carbohydrate percentage $=100-(\%$ protein $+\%$ fat $+\%$ moisture $+\%$ ash $)$. The $\mathrm{pH}$ values of the fermented products from the different treatments were measured using a digital $\mathrm{pH}$ meter equipped with a combined electrode (Hanna, Germany). Acidity was measured as described by Ling (1963).

\section{Phenolic compounds and total flavonoids of beetroot and stirred yoghurt samples}

Total phenolics and total flavonoid contents were determined colorimetrically in beetroot and different stirred yoghurt samples using Folin-Ciocalteu reagent (Singleton et al., 1999) and aluminum choloride method (Chang et al., 2002). Total phenolic content was expressed as gallic acid equivalents (GAE) in $\mathrm{mg} / \mathrm{g}$ sample, while total flavonoid content was expressed as mg quercetin equivalent per $g(\mathrm{QE})$. The results were expressed as mean $\pm \mathrm{SD}$.

\section{Antioxidant activity by DPPH radical scavenging method of beetroot and stirred yoghurt samples}

The free radical scavenging activity of beetroot and different stirred yoghurt samples was measured by 
1,1-diphenyl-2-picryl hydrazyl (DPPH). One $\mathrm{ml}$ of DPPH in ethanol $(0.1 \mathrm{mM})$ was added to three $\mathrm{ml}$ of beetroot and different stirred yoghurt samples $(250$, 500 , and $750 \mu \mathrm{g} / \mathrm{ml})$ or BHT as standard $(250,500$, and $750 \mu \mathrm{g} / \mathrm{ml})$. All samples and standard were shaken and stood at room temperature for $30 \mathrm{~min}$. The absorbance of samples and standard was measured at $517 \mathrm{~nm}$. The assay was carried out in triplicate, and the results are expressed as mean $\pm \mathrm{SD}$. The percentage of $\mathrm{DPPH}$ scavenging effect was calculated using the following equation:

DPPH scavenging effect, $\%$, or percent inhibition $=$

$$
=\left(A_{0}-A_{1} / A_{0}\right) \times 100
$$

where:

$$
\begin{aligned}
& A_{0}-\text { the absorbance of control reaction, } \\
& A_{1}-\text { the absorbance in presence of test or standard } \\
& \text { sample. }
\end{aligned}
$$

\section{Reducing power of beetroot and stirred yoghurt samples}

The reducing power of beetroot and different stirred yoghurt samples was determined. Beetroot and different stirred yoghurt samples $(1,2,3,4$, and $5 \mathrm{mg} / \mathrm{ml})$ in $1 \mathrm{ml}$ of methyl alcohol were mixed with phosphate buffer $(2.5 \mathrm{ml}, 0.2 \mathrm{M}, \mathrm{pH} 6.6)$ and $2.5 \mathrm{ml}$ of $1 \%$ potassium ferricyanide $\left[\mathrm{K}_{3} \mathrm{Fe}(\mathrm{CN})_{6}\right]$. The mixture was incubated at $50^{\circ} \mathrm{C}$ for $20 \mathrm{~min}$, and then $2.5 \mathrm{ml}$ of trichloroacetic acid $(10 \%)$ was added to the mixture. All samples were centrifuged $(1000 \times \mathrm{g})$ for $10 \mathrm{~min}$ and then $2.5 \mathrm{ml}$ from the upper layer was mixed with $2.5 \mathrm{ml}$ of distilled $\mathrm{H}_{2} \mathrm{O}$ and $0.5 \mathrm{ml}$ of $\mathrm{FeCl}_{3}(0.1 \%)$. The absorbance was measured at $700 \mathrm{~nm}$. The assay was carried out in triplicate, and the results are expressed as mean $\pm \mathrm{SD}$. Increase in absorbance of sample with concentrations indicates high reducing potential of the samples.

\section{Microbiological analysis of stirred yoghurt samples}

Stirred yoghurt samples $(10 \mathrm{~g})$ were homogenized for 1 min with $90 \mathrm{ml}$ of sterile $\mathrm{NaCl}(0.85 \%)$ as a sterile solution. Decimal dilutions were prepared in $9 \mathrm{ml}$ sterile $\mathrm{NaCl}(0.85 \%)$. The microbiological content of the stirred yoghurt samples was determined as follows: $B i$ fidobacterium counts were enumerated on MRS agar supplemented with $2 \mathrm{gm} / \mathrm{l}$ sodium propionate and $3 \mathrm{~g} / \mathrm{l}$ lithium chloride and the plates incubated at $37^{\circ} \mathrm{C}$ for $72 \mathrm{~h}$ under anaerobic conditions. Streptococci counts were enumerated using M17 agar acidified to $\mathrm{pH} 6.8$ by $1 \mathrm{M} \mathrm{HCl}$ and the plates incubated at $37 \pm 1^{\circ} \mathrm{C}$ for $48 \mathrm{~h}$ under aerobic conditions. Lactobacilli counts were determined using MRS agar and the plates incubated at $37 \pm 1^{\circ} \mathrm{C}$ for $72 \mathrm{~h}$ under anaerobic conditions. Yeasts and molds counts were enumerated by potato dextrose agar acidified to $\mathrm{pH} 3.5$ with sterile lactic acid solution and the plates aerobically incubated at $25^{\circ} \mathrm{C}$ for 4 days. Total bacterial counts were aerobically incubated using plate count agar at $25^{\circ} \mathrm{C}$ for $48 \mathrm{~h}$. Coliform groups were detected using Violet Red bile Agar (Difco) and the plates were incubated at $35^{\circ} \mathrm{C}$ for $24 \mathrm{~h}$. The results were recorded as a log number of colony-forming units per gm $\left(\log ^{10} \mathrm{CFU} / \mathrm{gm}\right)$.

\section{Rheological profile of stirred yoghurt samples}

Texture profile analysis (TPA) was carried out on the fermented samples using the double compression tester (Multi test 1d Memesin, Food Technology Corporation, Slinfold, W. Sussex, UK). Experiments were carried out by a compression test that generated a plot of force $(\mathrm{N})$ versus time (s). A 25-mm-diameter perplex conical-shaped probe was used to perform the TPA analysis at five different points on the sample surface. In the 1st stage, the sample was compressed by $30 \%$ of its original depth at a speed of $2 \mathrm{~cm} / \mathrm{min}$ during the pretest, compression, and the relaxation of the sample. From the force-time curve, the following parameters were determined:

Hardness, $\mathrm{N}=$ maximum force of the 1 st compression Cohesiveness $=$ area under the 2 nd compression / area under the 1 st compression $\left(A_{2} / A_{1}\right)$

Adhesiveness, $\mathrm{N} \cdot \mathrm{s}=$ negative area in the curve

Springiness, $\mathrm{mm}=$ length 2 nd compression / length 1st compression $\left(L_{2} / L_{1}\right)$

Gumminess, $\mathrm{N}=$ hardness 9 cohesiveness

Chewiness, $\mathrm{mJ}=$ gumminess 9 springiness

\section{Water holding capacity of stirred yoghurt samples}

Water holding capacity (WHC) was determined according to Arslan and Ozel (2012). 


\section{Apparent viscosity of stirred yoghurt samples}

Apparent viscosity was measured using a Brookfield DV digital viscometer (Brookfield Engineering, Middleborough, MA, USA) with spindle no. 4 at $60 \mathrm{rpm}$. Apparent viscosity was expressed as Pascal $-\mathrm{Pa} \cdot \mathrm{s}$.

\section{Color measurements of stirred yoghurt samples}

The color of the stirred yoghurt samples was measured using Hunter colorimeter Model D2s A-2 (Hunter Assoc. Lab. Inc. Va, USA) following the instructions of the manufacturer. The instrument was first standardized using a white tile (top of the scale) and a black tile (bottom of the scale). A specimen of the cheese (flat layer) was placed at the specimen port; the tri-stimulus values of the color namely $L, a$ and $b$ were measured where: $L$ - value represents darkness from black $(0)$ to white (100), $a$ - value represents color ranging from red $(+)$ to green $(-)$ and $b$ value represents yellow $(+)$ to blue $(-)$.

\section{Sensory evaluation of stirred yoghurt samples}

Stirred yoghurts' samples were evaluated for the following sensory attributes according to the 5-point hedonic test: flavor (out of 60 points), body and texture (out of 20 points), appearance (out of 10 points), and overall acceptability (sum of scores for different attributes). Taste panels of 10 panelists from the staff of the dairy department, National Research Centre, Cairo were involved in the sensory analysis. The judges were given distilled water to rinse their mouths in between samples. The samples were shown to the judges in a random order, and they were asked to give each parameter a score to indicate their approval.

\section{The effect of stirred yoghurt samples in high- -fat diet fed-streptozotocin (HFD/STZ)-damaged rat model}

\section{Animals}

Male Wister rats (9 weeks old) of $117.36 \pm 14.54 \mathrm{~g}$ as mean \pm SD were obtained from the animal house of the National Research Centre, Cairo, Egypt. Animals were kept individually in stainless steel cages under standard laboratory conditions $\left(23-25^{\circ} \mathrm{C}, 12 \mathrm{~h}\right.$ light/ dark cycle) and with free access to diet and water. This study has been carried out as a part of internal project no 12050203 in the National Research Centre, Cairo,
Egypt. This project was approved by the Medical Research Ethics Committee, National Research Centre, Cairo, Egypt with approval number 19176, and followed the recommendations of the National Institutes of Health Guide for Care and Use of Laboratory Animals (Publication no. 85-23, revised 1985).

\section{Animals' diet}

Balanced diet (12\% casein as a protein source, $10 \%$ corn oil, $10 \%$ sucrose, $58.5 \%$ maize starch, $5 \%$ fiber, $3.5 \%$ salt mixture, and $1 \%$ vitamin mixture), salt, and vitamin mixtures were prepared in accordance with AIN-93 (Reeves et al., 1993). A high fat diet (12\% casein as a protein source, $20 \%$ saturated fat, $1 \%$ cholesterol, $10 \%$ sucrose, $52.5 \%$ maize starch, $3.5 \%$ salt mixture, and $1 \%$ vitamin mixture) was prepared according to Zhu et al. (2017) with a slight modification through the use of saturated fats.

\section{Type 2 diabetes induction}

Thirty rats were assigned to two dietary groups. The first group (6 rats) was served as normal healthy control and received a balanced diet. To induce rat model of type 2 diabetes, according to the protocols of Srinivasan et al. (2005), twenty-four rats (the second group) were fed a high fat-high cholesterol diet for a month and then given a single intraperitoneal injection $45 \mathrm{mg} / \mathrm{kg}$ body weight (w/w) of streptozotocin (STZ) (from Sigma chemical Co) in citrate buffer, $\mathrm{pH}$ 4.5. The onset of diabetes in rats was confirmed by the high blood glucose concentration $(>150 \mathrm{mg} / \mathrm{dl}) 72 \mathrm{~h}$ after streptozotocin injection.

\section{Design of the experiment}

Group 1 (CN, control group) fed on a balanced diet all over the experimental period (two months). After the induction of type 2 diabetes, the diabetic rats were divided into 4 sub-groups of 6 rats each as follow:

Group 2 (D-HFT), diabetic rats fed on the same high fat-high cholesterol diet.

Group 3 (D-HFD + CY), diabetic rats fed on the same high fat-high cholesterol diet and orally given $1 \mathrm{ml}$ of control stirred yoghurt once daily for a month.

Group 4 (D-HFD $+1 \% \mathrm{Y}$ ), diabetic rats fed on the same high fat-high cholesterol diet and orally given $1 \mathrm{ml}$ of probiotic stirred yoghurt fortified with $1 \%$ beetroot powder once daily for a month. 
Group 5 (D-HFD $+2 \% \mathrm{Y}$ ), diabetic rats fed on the same high fat-high cholesterol diet and orally given $1 \mathrm{ml}$ of probiotic stirred yoghurt fortified with $2 \%$ beetroot powder once daily for a month.

At the end of one month of the experiment (diabetes induction period) and at the end of the experiment, total food intake, body weight gain and feed efficiency ratio were calculated. After blood collecting, the heart and liver were immediately removed from each rat, weighed, and impressed in $10 \%$ formalin solution for the histopathological examinations.

\section{Biochemical analysis}

Plasma was analyzed for blood glucose, glycated haemoglobin $(\mathrm{HbAlc})$, creatinine and urea using colorimetric kits. Insulin resistance (IR) estimation was carried out using the homeostasis model assessment method and HOMA-IR was calculated using the following equation:

Plasma glucose in the fasting state, $\mathrm{mmol} / \mathrm{l} \times$ fasting plasma insulin, $\mathrm{mU} / 1$, divided by 22.5 .

The activity of aspartate transaminase (AST) and alanine transaminase (ALT) were determined using colorimetric kits. Plasma total cholesterol (T-Ch), high-density lipoprotein cholesterol (HDL-Ch), low-density lipoprotein cholesterol (LDL-Ch), and triglycerides (TG) were determined using colorimetric kits. Non-HDL cholesterol and very low low-density lipoprotein (VLDL) as well as T-Ch/HDL-Ch ratio and TGs/HDL-Ch ratio were calculated. Plasma was also analyzed for malondialdehyde (MDA), insulin, thyroid stimulating hormone (TSH), and C-reactive protein (CRP) using Eliza kits.

\section{Microbial analysis of rats' feces}

On the first day, at the end of the diabetes induction period and at the end of the experiment, fresh feces' samples of rats were collected for $24 \mathrm{~h}$. The microbiological characteristics of these feces samples were detected by serial decimal dilution prepared in $9 \mathrm{ml}$ sterile $\mathrm{NaCl}(0.85 \%)$ as the following: Bifidobacterium counts were enumerated on MRS agar supplemented with $2 \mathrm{gm} / 1$ sodium propionate and $3 \mathrm{gm} / 1$ lithium chloride and the plates incubated at $37^{\circ} \mathrm{C}$ for $72 \mathrm{~h}$ under anaerobic condition. Lactobacilli counts were determined using MRS agar and the plates incubated at $37^{\circ} \mathrm{C}$ for $72 \mathrm{~h}$ under anaerobic conditions. Total bacterial counts were aerobically incubated using plate count agar at $25^{\circ} \mathrm{C}$ for $48 \mathrm{~h}$. Coliform groups were detected using Violet Red bile Agar (Difco) and the plates were incubated at $35^{\circ} \mathrm{C}$ for $24 \mathrm{~h}$.

\section{Histopathological examination}

Liver and heart tissues were rinsed three times in $70 \%$ ethanol, dehydrated using a graded ethanol series, and then embedded in paraffin wax. Paraffin sections were cut into 5 micrometers-thick slices and stained with haematoxylin and eosin for light microscope examination. The sections were viewed and photographed using a digital microscope (Olympus BX50, Japan).

\section{Statistical analysis}

Results of the nutritional parameters and the microbial counts of rats' feces after one month of the animal study were statistically analyzed via Student's $t$-test. Other data were analyzed statistically using the one-way analysis of variance ANOVA followed by Duncan's test using SPSS software program version 16.

\section{RESULTS AND DISCUSSION}

Table 1 indicates that the value of the total solids increased significantly over the period of storage in all the samples of stirred yoghurt. The probiotic stirred yoghurt fortified with $2 \%$ beetroot powder had a higher value of total solids than the probiotic stirred yoghurt fortified with $1 \%$ beetroot powder and the control stirred yoghurt either fresh or during cold storage at $5^{\circ} \mathrm{C}$ for 15 days. It could be noticed that supplementation of stirred yoghurt with beetroot powder associated with the increasing of fat, total protein, carbohydrates, and ash. These increases are due to the relative increase of these nutrients in beetroot powder.

As illustrated in Figure 1, beetroot showed the highest content of total phenolic compounds and total flavonoids followed by stirred yoghurt containing probiotic and $2 \%$ beetroot powder. Stirred yoghurt containing only probiotic was the lowest in total phenolic compounds and total flavonoids. The content of total phenolic of probiotic fortified stirred yoghurt is related to the fortification with beetroot powder as beetroot is a good source of polyphenols as confirmed in our results and the results of Barbu et al. (2020) who 
Mohamed, D. A., El-Sayed, H. S., Abd El-Gawad, M. A. M., Abdelgayed, S. S., Hamed, I. M., Mohamed, R. S. (2021). Characterization of stirred yoghurt enriched with probiotics and beetroot and its therapeutic potential in experimental type 2 diabetes. Acta Sci. Pol. Technol. Aliment., 20(4), 429-448. http://dx.doi.org/10.17306/J.AFS.2021.0953

Table 1. Change in chemical composition of stirred yoghurt samples during storage period at $5 \pm 2{ }^{\circ} \mathrm{C}$ for 15 days

\begin{tabular}{|c|c|c|c|c|c|c|}
\hline \multirow{2}{*}{ Parameters } & \multirow{2}{*}{ Sample } & \multicolumn{4}{|c|}{ Storage period, days } & \multirow{2}{*}{$p$-value } \\
\hline & & zero & 5 & 10 & 15 & \\
\hline \multirow[t]{3}{*}{ TS\% } & control & $15.61^{\mathrm{a}} \pm 0.002$ & $15.75^{\mathrm{a}} \pm 0.03$ & $15.94^{\mathrm{a}} \pm 0.003$ & $16.18^{\mathrm{a}} \pm 0.003$ & 0.000 \\
\hline & $\mathrm{T} 1$ & $16.57^{\mathrm{a}} \pm 0.01$ & $16.74^{b} \pm 0.02$ & $16.89^{\mathrm{c}} \pm 0.02$ & $17.15^{\mathrm{d}} \pm 0.01$ & 0.000 \\
\hline & $\mathrm{T} 2$ & $17.14^{\mathrm{a}} \pm 0.01$ & $17.31^{\mathrm{b}} \pm 0.02$ & $17.80^{\mathrm{c}} \pm 0.01$ & $18.03^{\mathrm{d}} \pm 0.04$ & 0.000 \\
\hline \multirow[t]{3}{*}{ ТР\% } & control & $4.35^{\mathrm{b}} \pm 0.01$ & $3.70^{\mathrm{a}} \pm 0.33$ & $4.36^{\mathrm{b}} \pm 0.01$ & $4.41^{b} \pm 0.02$ & 0.044 \\
\hline & $\mathrm{T} 1$ & $4.87^{\mathrm{a}} \pm 0.24$ & $4.38^{\mathrm{a}} \pm 0.01$ & $4.40^{\mathrm{a}} \pm 0.01$ & $4.60^{\mathrm{a}} \pm 0.22$ & 0.207 \\
\hline & $\mathrm{T} 2$ & $4.46^{\mathrm{a}} \pm 0.01$ & $4.46^{\mathrm{a}} \pm 0.01$ & $4.46^{\mathrm{a}} \pm 0.02$ & $4.49^{\mathrm{a}} \pm 0.02$ & 0.266 \\
\hline \multirow[t]{3}{*}{ Fat $\%$} & control & $3.53^{\mathrm{a}} \pm 0.10$ & $3.54^{\mathrm{a}} \pm 0.10$ & $3.61^{\mathrm{a}} \pm 0.02$ & $3.62^{\mathrm{a}} \pm 0.01$ & 0.686 \\
\hline & $\mathrm{T} 1$ & $3.62^{\mathrm{a}} \pm 0.01$ & $3.62^{\mathrm{a}} \pm 0.01$ & $3.64^{\mathrm{ab}} \pm 0.01$ & $3.66^{\mathrm{b}} \pm 0.01$ & 0.045 \\
\hline & $\mathrm{T} 2$ & $3.66^{\mathrm{a}} \pm 0.01$ & $3.67^{\mathrm{a}} \pm 0.01$ & $3.67^{\mathrm{a}} \pm 0.01$ & $3.70^{\mathrm{a}} \pm 0.02$ & 0.169 \\
\hline \multirow[t]{3}{*}{$\mathrm{Ash} \%$} & control & $0.80^{\mathrm{a}} \pm 0.01$ & $0.82^{\mathrm{a}} \pm 0.01$ & $0.80^{\mathrm{a}} \pm 0.01$ & $0.82^{\mathrm{a}} \pm 0.01$ & 0.560 \\
\hline & $\mathrm{T} 1$ & $0.80^{\mathrm{a}} \pm 0.01$ & $0.81^{\mathrm{ab}} \pm 0.01$ & $0.84^{\mathrm{bc}} \pm 0.01$ & $0.85^{\mathrm{c}} \pm 0.01$ & 0.028 \\
\hline & $\mathrm{T} 2$ & $0.83^{\mathrm{ab}} \pm 0.01$ & $0.82^{\mathrm{a}} \pm 0.01$ & $0.83^{\mathrm{ab}} \pm 0.01$ & $0.86^{\mathrm{b}} \pm 0.01$ & 0.110 \\
\hline \multirow[t]{3}{*}{ Carbohydrate } & control & $6.73^{a} \pm 0.02$ & $6.90^{\mathrm{b}} \pm 0.01$ & $7.04^{\mathrm{c}} \pm 0.02$ & $7.22^{\mathrm{d}} \pm 0.01$ & 0.000 \\
\hline & $\mathrm{T} 1$ & $7.74^{\mathrm{a}} \pm 0.05$ & $7.85^{\mathrm{a}} \pm 0.05$ & $8.03^{b} \pm 0.02$ & $8.26^{c} \pm 0.08$ & 0.001 \\
\hline & $\mathrm{T} 2$ & $8.29^{\mathrm{a}} \pm 0.05$ & $8.43^{\mathrm{a}} \pm 0.03$ & $8.95^{\mathrm{b}} \pm 0.04$ & $9.10^{c} \pm 0.05$ & 0.000 \\
\hline
\end{tabular}

The same letter in each row denotes a non-significant difference, whereas a different letter denotes a significant difference by Duncan's test. The confidence level is $95 \%$. The data are expressed as mean values \pm standard error.

TS - total solids, TP - total protein, control - probiotic stirred yoghurt, T1 - probiotic stirred yoghurt -fortified by $1 \%$ beetroot powder, $\mathrm{T} 2$ - probiotic stirred yoghurt fortified by $2 \%$ beetroot powder.

reported that beetroot is a good source of flavonoids and phenolic compounds including betalains, gallic, syringic, and caffeic acids.

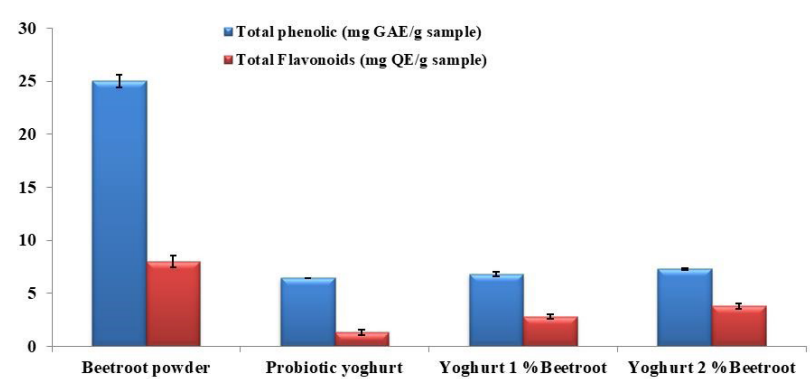

Fig. 1. Total phenolic compounds and total flavonoids contents in beetroot and different stirred yoghurt samples
As illustrated in Figure 2, free radical scavenger activity was increased with the increment of concentration of all samples or standard. BHT showed the highest free radical scavenger activity in all used concentration compared with beetroot powder or different stirred yoghurt samples. Beetroot powder was the highest scavenger of DPPH radical compared with all stirred yoghurt samples, followed by stirred yoghurt containing probiotic and $2 \%$ beetroot powder, while stirred yoghurt containing probiotic only was the lowest scavenger of the DPPH radical. Barbu et al. (2020) reported that the antioxidant activity of beetroot is mainly due to its betalains (betacyanins, betaxanthins, betanin and isobetanin) content. He also found that adding probiotic bacteria (Lactobacillus plantarum) to fresh beet slices increased the concentration 


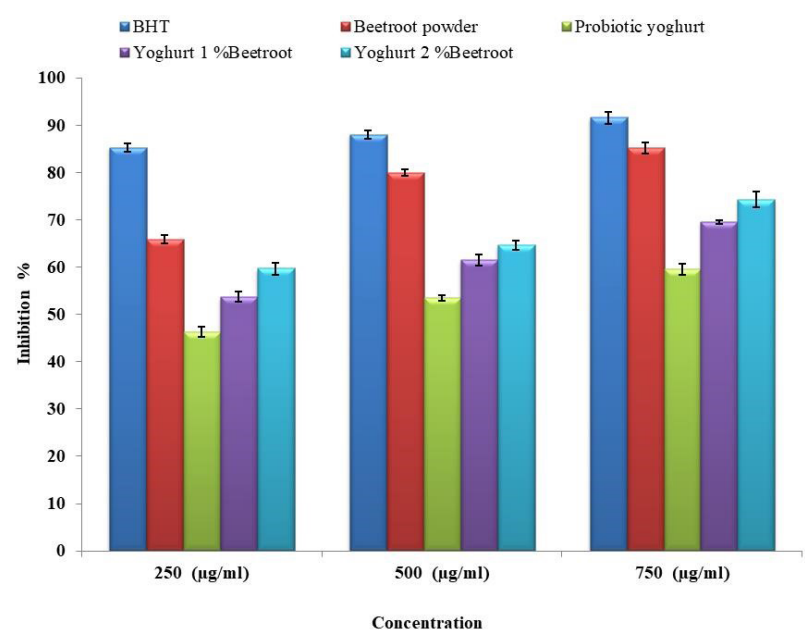

Fig. 2. Free radical scavenger activity of BHT, beetroot powder and stirred yoghurt samples

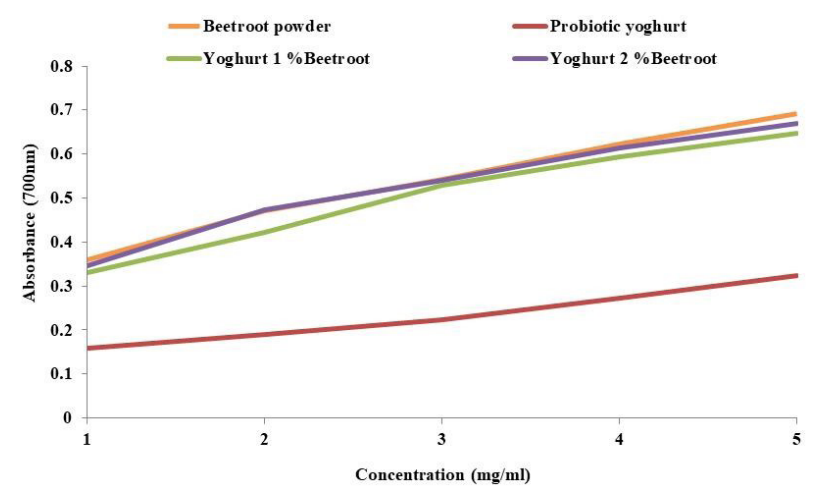

Fig. 3. Reducing power activity of BHT, beetroot powder, and stirred yoghurt samples

of betalains, and this was attributed to the possibility of extractability increasing of betalains. Thus, in our study, the combination of beetroot and probiotics may be behind the antioxidant activity of the fortified stirred yoghurt.

As shown in Figure 3, beetroot powder was the highest in reducing power followed by stirred yoghurt containing probiotic and $2 \%$ beetroot powder. Stirred yoghurt containing probiotic only was the lowest in reducing power. The reducing power activity increased with the increment of all sample's concentration.

As shown in Table 2, the acidity increased gradually, while the $\mathrm{pH}$ decreased in the stirred yoghurt supplemented with beetroot powder. This might be due to the acid production in the experimental stirred yoghurt during storage as a result of the fermentation of lactose by the action of the starter cultures. The $\mathrm{pH}$ of the stirred yoghurt samples was decreased by addition of beetroot powder due to the acidic nature of beetroot. The water holding capacity (WHC) was recorded as having a higher value in control than stirred yoghurt fortified with beetroot powder. The addition of beetroot powder caused a decrease of water holding capacity in all treatments, while WHC increased during cold storage at $5^{\circ} \mathrm{C}$ for 15 days for all stirred yoghurt samples. The effect of beetroot powder on the water holding capacity may be attributed to the presence of fiber retaining more aqueous phase and/or the increased softness of the gel matrix.

Instrumental measurements of color are based on the determination of three parameters, i.e., $L$ (\% whiteness), $a$ color red $(+)$ to green $(-)$ and $b$ color yellow $(+)$ to blue $(-)$. Table 3 shows decreases in whiteness with the increased percentage of added beetroot powder in stirred yoghurt which can be attributed to the reddish color of beetroot powder. The $a$ value of stirred yoghurt increased with the increase of beetroot powder in stirred yoghurt fortified with beetroot powder. The reddish degree was increased in probiotic stirred yoghurt fortified with either $1 \%$ beetroot powder or $2 \%$ beetroot but remained stable in control during cold storage period at $5^{\circ} \mathrm{C}$ for 15 days.

As shown in Table 3, all yoghurt samples had acceptability at the zero time. Control samples molded after 15 days of storage. The stirred yoghurt fortified with beetroot powder had higher scores for flavor than the control yoghurt. The probiotic stirred yoghurt fortified with $1 \%$ beetroot powder recorded the most acceptability until the end of storage period compared with the probiotic stirred yoghurt fortified with $2 \%$ beetroot powder and control yoghurt. Generally, fortification of the stirred yoghurt with beetroot powder improved the sensory properties and extent of the self-life. Because the nutrients were more easily accessible from beetroot, the lactic fermentation process occurred, contributing to the unique organoleptic impression of the stirred yoghurt.

As illustrated in Figure 4, the viscosity of the stirred yoghurt fortified with $2 \%$ of beetroot increased over the storage period. This may be due to an increase 
Mohamed, D. A., El-Sayed, H. S., Abd El-Gawad, M. A. M., Abdelgayed, S. S., Hamed, I. M., Mohamed, R. S. (2021). Characterization of stirred yoghurt enriched with probiotics and beetroot and its therapeutic potential in experimental type 2 diabetes. Acta Sci. Pol. Technol. Aliment., 20(4), 429-448. http://dx.doi.org/10.17306/J.AFS.2021.0953

Table 2. Change in $\mathrm{pH}$, acidity $\%$, and physical properties of stirred yoghurt samples during storage period at $5 \pm 2{ }^{\circ} \mathrm{C}$ for 15 days

\begin{tabular}{|c|c|c|c|c|c|c|}
\hline \multirow{2}{*}{ Parameters } & \multirow{2}{*}{ Samples } & \multicolumn{4}{|c|}{ Storage period, days } & \multirow{2}{*}{$p$-value } \\
\hline & & zero & 5 & 10 & 15 & \\
\hline \multirow[t]{3}{*}{$\mathrm{pH}$} & control & $4.85^{\mathrm{c}} \pm 0.01$ & $4.81^{b} \pm 0.01$ & $4.77^{\mathrm{a}} \pm 0.01$ & $4.74^{\mathrm{a}} \pm 0.01$ & 0.000 \\
\hline & $\mathrm{T} 1$ & $4.84^{c} \pm 0.01$ & $4.74^{b} \pm 0.01$ & $4.69^{\mathrm{a}} \pm 0.01$ & $4.67^{\mathrm{a}} \pm 0.01$ & 0.000 \\
\hline & $\mathrm{T} 2$ & $4.78^{c} \pm 0.01$ & $4.67^{b} \pm 0.01$ & $4.66^{\mathrm{b}} \pm 0.01$ & $4.60^{\mathrm{a}} \pm 0.01$ & 0.000 \\
\hline \multirow[t]{3}{*}{ Acidity $\%$} & control & $0.95^{\mathrm{a}} \pm 0.01$ & $1.01^{\mathrm{a}} \pm 0.01$ & $1.14^{\mathrm{b}} \pm 0.01$ & $1.19^{b} \pm 0.03$ & 0.000 \\
\hline & $\mathrm{T} 1$ & $1.21^{\mathrm{a}} \pm 0.01$ & $1.26^{\mathrm{b}} \pm 0.01$ & $1.31^{\mathrm{c}} \pm 0.01$ & $1.34^{\mathrm{d}} \pm 0.01$ & 0.000 \\
\hline & $\mathrm{T} 2$ & $1.29^{\mathrm{a}} \pm 0.01$ & $1.31^{\mathrm{ab}} \pm 0.01$ & $1.34^{\mathrm{b}} \pm 0.01$ & $1.40^{\mathrm{c}} \pm 0.01$ & 0.000 \\
\hline \multirow[t]{3}{*}{ WHC\% } & control & $11.70^{\mathrm{a}} \pm 0.33$ & $14.00^{b} \pm 0.23$ & $18.05^{\mathrm{c}} \pm 0.23$ & $21.04^{\mathrm{d}} \pm 0.13$ & 0.000 \\
\hline & $\mathrm{T} 1$ & $10.74^{\mathrm{a}} \pm 0.32$ & $10.60^{\mathrm{a}} \pm 0.21$ & $15.92^{b} \pm 0.05$ & $15.78^{\mathrm{b}} \pm 0.35$ & 0.000 \\
\hline & $\mathrm{T} 2$ & $9.17^{\mathrm{a}} \pm 0.16$ & $10.72^{b} \pm 0.56$ & $13.42^{\mathrm{c}} \pm 0.42$ & $12.46^{\mathrm{c}} \pm 0.33$ & 0.000 \\
\hline \multirow[t]{3}{*}{ Hardness } & control & $0.05^{\mathrm{a}} \pm 0.01$ & $0.41^{b} \pm 0.01$ & $0.85^{\mathrm{c}} \pm 0.04$ & $0.85^{\mathrm{c}} \pm 0.10$ & 0.000 \\
\hline & $\mathrm{T} 1$ & $0.08^{\mathrm{a}} \pm 0.01$ & $0.52^{b} \pm 0.01$ & $0.94^{\mathrm{c}} \pm 0.01$ & $0.84^{c} \pm 0.10$ & 0.000 \\
\hline & $\mathrm{T} 2$ & $0.12^{\mathrm{a}} \pm 0.01$ & $0.73^{b} \pm 0.01$ & $0.97^{\mathrm{c}} \pm 0.01$ & $0.94^{c} \pm 0.11$ & 0.000 \\
\hline \multirow[t]{3}{*}{ Cohesiveness } & control & $0.63^{\mathrm{a}} \pm 0.10$ & $0.43^{\mathrm{a}} \pm 0.02$ & $0.49^{\mathrm{a}} \pm 0.06$ & $0.50^{\mathrm{a}} \pm 0.08$ & 0.294 \\
\hline & $\mathrm{T} 1$ & $0.53^{c} \pm 0.05$ & $0.38^{\mathrm{ab}} \pm 0.05$ & $0.46^{\mathrm{bc}} \pm 0.02$ & $0.27^{\mathrm{a}} \pm 0.06$ & 0.016 \\
\hline & $\mathrm{T} 2$ & $0.47^{\mathrm{a}} \pm 0.07$ & $0.39^{\mathrm{a}} \pm 0.03$ & $0.36^{a} \pm 0.06$ & $0.52^{\mathrm{a}} \pm 0.07$ & 0.256 \\
\hline \multirow[t]{3}{*}{ Springiness } & control & $0.77^{\mathrm{c}} \pm 0.03$ & $0.42^{\mathrm{a}} \pm 0.03$ & $0.59^{\mathrm{b}} \pm 0.04$ & $0.54^{b} \pm 0.04$ & 0.001 \\
\hline & $\mathrm{T} 1$ & $0.71^{b} \pm 0.03$ & $0.43^{\mathrm{a}} \pm 0.06$ & $0.58^{\mathrm{ab}} \pm 0.04$ & $0.48^{\mathrm{a}} \pm 0.04$ & 0.012 \\
\hline & $\mathrm{T} 2$ & $0.57^{b} \pm 0.04$ & $0.38^{\mathrm{a}} \pm 0.03$ & $0.52^{\mathrm{b}} \pm 0.04$ & $0.53^{b} \pm 0.05$ & 0.044 \\
\hline \multirow[t]{3}{*}{ Gumminess } & control & $0.03^{\mathrm{a}} \pm 0.01$ & $0.17^{b} \pm 0.01$ & $0.34^{\mathrm{c}} \pm 0.02$ & $0.29^{\mathrm{bc}} \pm 0.07$ & 0.002 \\
\hline & $\mathrm{T} 1$ & $0.04^{\mathrm{a}} \pm 0.01$ & $0.25^{\mathrm{b}} \pm 0.01$ & $0.43^{\mathrm{c}} \pm 0.10$ & $0.24^{b} \pm 0.02$ & 0.005 \\
\hline & $\mathrm{T} 2$ & $0.05^{\mathrm{a}} \pm 0.01$ & $0.36^{b} \pm 0.02$ & $0.44^{b} \pm 0.02$ & $0.42^{b} \pm 0.05$ & 0.000 \\
\hline \multirow[t]{3}{*}{ Chewiness } & control & $0.14^{\mathrm{a}} \pm 0.12$ & $0.05^{\mathrm{a}} \pm 0.01$ & $0.18^{\mathrm{a}} \pm 0.01$ & $0.23^{\mathrm{a}} \pm 0.02$ & 0.227 \\
\hline & $\mathrm{T} 1$ & $0.03^{a} \pm 0.01$ & $0.07^{\mathrm{ab}} \pm 0.01$ & $0.15^{\mathrm{b}} \pm 0.07$ & $0.13^{\mathrm{ab}} \pm 0.02$ & 0.125 \\
\hline & $\mathrm{T} 2$ & $0.03^{\mathrm{a}} \pm 0.01$ & $0.14^{b} \pm 0.01$ & $0.28^{c} \pm 0.02$ & $0.26^{c} \pm 0.03$ & 0.000 \\
\hline
\end{tabular}

The same letter in each row denotes a non-significant difference, whereas a different letter denotes a significant difference by Duncan's test. The confidence level is $95 \%$. The data are expressed as mean values \pm standard error.

TS - total solids, TP - total protein, control - probiotic stirred yoghurt, T1 - probiotic stirred yoghurt fortified by $1 \%$ beetroot powder, $\mathrm{T} 2-$ probiotic stirred yoghurt fortified by $2 \%$ beetroot powder.

in the total solids in addition to the presence of beet- beetroot compared to the control yoghurt. The Bifiroot powder.

Data in Table 4 show that Bifidobacterium counts dobacterium counts significantly improved with the were significantly higher in stirred yoghurt containing storage period in all samples. It increased 0.22 and 1.13 log cycle for stirred yoghurt T1 and T2 samples, 
Mohamed, D. A., El-Sayed, H. S., Abd El-Gawad, M. A. M., Abdelgayed, S. S., Hamed, I. M., Mohamed, R. S. (2021). Characterization of stirred yoghurt enriched with probiotics and beetroot and its therapeutic potential in experimental type 2 diabetes. Acta Sci. Pol. Technol. Aliment., 20(4), 429-448. http://dx.doi.org/10.17306/J.AFS.2021.0953

Table 3. Changes in color and sensorial properties of stirred yoghurt samples during storage period at $5 \pm 2^{\circ} \mathrm{C}$ for 15 days

\begin{tabular}{|c|c|c|c|c|c|c|}
\hline \multirow{2}{*}{ Parameters } & \multirow{2}{*}{ Samples } & \multicolumn{4}{|c|}{ Storage period, days } & \multirow{2}{*}{$p$-value } \\
\hline & & zero & 5 & 10 & 15 & \\
\hline \multicolumn{7}{|c|}{ Color } \\
\hline \multirow[t]{3}{*}{$L^{*}$} & control & $93.69^{d} \pm 0.01$ & $93.61^{\mathrm{c}} \pm 0.02$ & $93.50^{b} \pm 0.01$ & $93.45^{\mathrm{a}} \pm 0.01$ & 0.000 \\
\hline & $\mathrm{T} 1$ & $66.25^{\mathrm{a}} \pm 0.02$ & $86.71^{\mathrm{d}} \pm 0.01$ & $71.23^{b} \pm 0.02$ & $73.69^{c} \pm 0.03$ & 0.000 \\
\hline & $\mathrm{T} 2$ & $58.70^{\mathrm{a}} \pm 0.01$ & $60.41^{\mathrm{b}} \pm 0.02$ & $62.13^{c} \pm 0.03$ & $63.82^{\mathrm{d}} \pm 0.03$ & 0.000 \\
\hline \multirow[t]{3}{*}{$a^{*}$} & control & $-1.06 \pm 0.01$ & $-1.31 \pm 0.02$ & $-1.55 \pm 0.03$ & $-1.79 \pm 0.02$ & 0.000 \\
\hline & $\mathrm{T} 1$ & $26.07^{\mathrm{d}} \pm 0.03$ & $20.72^{\mathrm{c}} \pm 0.04$ & $15.24^{b} \pm 0.18$ & $10.68^{\mathrm{a}} \pm 0.22$ & 0.000 \\
\hline & $\mathrm{T} 2$ & $27.81^{\mathrm{d}} \pm 0.02$ & $23.21^{\mathrm{c}} \pm 0.02$ & $18.71^{\mathrm{b}} \pm 0.02$ & $14.21^{\mathrm{a}} \pm 0.01$ & 0.000 \\
\hline \multirow[t]{3}{*}{$b^{*}$} & control & $14.37^{\mathrm{a}} \pm 0.12$ & $15.09^{\mathrm{b}} \pm 0.01$ & $15.69^{\mathrm{c}} \pm 0.02$ & $16.29^{\mathrm{d}} \pm 0.03$ & 0.000 \\
\hline & $\mathrm{T} 1$ & $0.78^{\mathrm{a}} \pm 0.03$ & $5.53^{b} \pm 0.02$ & $10.27^{\mathrm{c}} \pm 0.02$ & $15.25^{\mathrm{d}} \pm 0.28$ & 0.000 \\
\hline & $\mathrm{T} 2$ & $1.38^{\mathrm{a}} \pm 0.02$ & $10.84^{b} \pm 0.02$ & $20.31^{\mathrm{c}} \pm 0.02$ & $29.79^{\mathrm{d}} \pm 0.02$ & 0.000 \\
\hline \multicolumn{7}{|c|}{ Sensorial properties } \\
\hline \multirow[t]{3}{*}{ Flavor } & control & $55.70^{\mathrm{a}} \pm 0.42$ & $55.50^{\mathrm{a}} \pm 0.34$ & $55.30^{\mathrm{a}} \pm 0.52$ & $55.40^{\mathrm{a}} \pm 0.48$ & 0.931 \\
\hline & $\mathrm{T} 1$ & $56.40^{\mathrm{a}} \pm 0.48$ & $57.20^{\mathrm{a}} \pm 0.44$ & $57.50^{\mathrm{a}} \pm 0.50$ & $56.70^{\mathrm{a}} \pm 0.60$ & 0.429 \\
\hline & $\mathrm{T} 2$ & $57.60^{\mathrm{c}} \pm 0.48$ & $56.10^{\mathrm{b}} \pm 0.41$ & $55.40^{\mathrm{b}} \pm 0.48$ & $50.90^{\mathrm{a}} \pm 0.50$ & 0.000 \\
\hline \multirow[t]{3}{*}{ Appearance } & control & $8.80^{c} \pm 0.33$ & $8.60^{c} \pm 0.31$ & $7.30^{\mathrm{b}} \pm 0.30$ & $6.00^{\mathrm{a}} \pm 0.33$ & 0.000 \\
\hline & $\mathrm{T} 1$ & $9.30^{b} \pm 0.26$ & $8.90^{\mathrm{b}} \pm 0.28$ & $9.00^{\mathrm{b}} \pm 0.26$ & $7.60^{\mathrm{a}} \pm 0.37$ & 0.001 \\
\hline & $\mathrm{T} 2$ & $8.90^{c} \pm 0.28$ & $7.80^{\mathrm{b}} \pm 0.33$ & $7.20^{\mathrm{b}} \pm 0.36$ & $5.20^{\mathrm{a}} \pm 0.33$ & 0.000 \\
\hline \multirow{3}{*}{$\begin{array}{l}\text { Body } \\
\text { and texture }\end{array}$} & control & $28.40^{\mathrm{b}} \pm 0.45$ & $28.20^{\mathrm{b}} \pm 0.44$ & $28.40^{\mathrm{b}} \pm 0.37$ & $25.60^{\mathrm{a}} \pm 0.37$ & 0.000 \\
\hline & $\mathrm{T} 1$ & $29.00^{c} \pm 0.33$ & $28.40^{\mathrm{bc}} \pm 0.37$ & $27.50^{\mathrm{ab}} \pm 0.40$ & $26.80^{\mathrm{a}} \pm 0.44$ & 0.002 \\
\hline & $\mathrm{T} 2$ & $28.80^{\mathrm{c}} \pm 0.29$ & $25.80^{\mathrm{b}} \pm 0.42$ & $25.40^{\mathrm{ab}} \pm 0.58$ & $24.20^{\mathrm{a}} \pm 0.42$ & 0.000 \\
\hline
\end{tabular}

The same letter in each row denotes a non-significant difference, whereas a different letter denotes a significant difference by Duncan's test. The confidence level is $95 \%$. The data are expressed as mean values \pm standard error.

TS - total solids, TP - total protein, control - probiotic stirred yoghurt, T1 - probiotic stirred yoghurt fortified by $1 \%$ beetroot powder, T2 - probiotic stirred yoghurt fortified by $2 \%$ beetroot powder.

respectively. Similarly, counts of Lactobacilli with $1 \%$ and $2 \%$ beetroot increased gradually during cold storage. The increases for lactobacilli reached 0.66 and $0.88 \mathrm{log}$ cycle for stirred yoghurt fortified with $1 \%$ and $2 \%$ beetroot samples, respectively. The same trend of results was observed for streptococci as the counts gradually increased during storage. The counts reached 9.11, 9.77 and $10.30 \log \mathrm{CFU} / \mathrm{ml}$ for control, stirred yoghurt fortified with $1 \%$ and $2 \%$ beetroot samples, respectively, at the end of storage. Also, our results found little increase in the total bacterial counts of stirred yoghurt samples during the storage periods. The increases in total bacterial counts were recorded as $0.48,0.63$, and $1.03 \mathrm{log}$ cycle for control, stirred yoghurt fortified with $1 \%$ and $2 \%$ beetroot samples, respectively. Moreover, there were no detected counts for mold and yeast for the first five days. A few counts were detected later at 10 days of storage. These counts reached 1.57, 1.75, and $1.75 \log \mathrm{CFU} / \mathrm{ml}$ for control, stirred yoghurt fortified with $1 \%$ and $2 \%$ beetroot 
Mohamed, D. A., El-Sayed, H. S., Abd El-Gawad, M. A. M., Abdelgayed, S. S., Hamed, I. M., Mohamed, R. S. (2021). Characterization of stirred yoghurt enriched with probiotics and beetroot and its therapeutic potential in experimental type 2 diabetes. Acta Sci. Pol. Technol. Aliment., 20(4), 429-448. http://dx.doi.org/10.17306/J.AFS.2021.0953

Table 4. Microbiological analysis of stirred yoghurt samples during cold storage at $5 \pm 2{ }^{\circ} \mathrm{C}$ for 15 days

\begin{tabular}{|c|c|c|c|c|}
\hline \multirow{2}{*}{ Microorganisms } & \multirow{2}{*}{$\begin{array}{c}\text { Time of storage } \\
\text { day }\end{array}$} & \multicolumn{3}{|c|}{ Yoghurt' samples } \\
\hline & & control & $\mathrm{T} 1$ & $\mathrm{~T} 2$ \\
\hline \multirow{4}{*}{$\begin{array}{l}\text { Bifidobacterium } \\
\text { lactis }\end{array}$} & zero & $9.05^{\mathrm{ab}} \pm 0.03$ & $9.14^{\mathrm{a}} \pm 0.03$ & $9.20^{\mathrm{a}} \pm 0.46$ \\
\hline & 5 & $9.15^{b} \pm 0.03$ & $9.25^{\mathrm{b}} \pm 0.02$ & $9.89^{\mathrm{ab}} \pm 0.01$ \\
\hline & 10 & $8.45^{\mathrm{a}} \pm 0.37$ & $9.31^{\mathrm{bc}} \pm 0.04$ & $10.31^{\mathrm{b}} \pm 0.01$ \\
\hline & 15 & $9.13^{b} \pm 0.06$ & $9.36^{c} \pm 0.02$ & $10.33^{b} \pm 0.06$ \\
\hline$p$-value & & 0.050 & 0.004 & 0.028 \\
\hline \multirow[t]{4}{*}{ Lactobacilli } & zero & $9.13^{\mathrm{a}} \pm 0.01$ & $9.19^{\mathrm{a}} \pm 0.01$ & $9.40^{\mathrm{a}} \pm 0.03$ \\
\hline & 5 & $7.17^{\mathrm{ab}} \pm 0.02$ & $9.26^{\mathrm{a}} \pm 0.04$ & $9.75^{\mathrm{b}} \pm 0.03$ \\
\hline & 10 & $9.19^{\mathrm{b}} \pm 0.01$ & $9.74^{\mathrm{b}} \pm 0.07$ & $10.26^{\mathrm{c}} \pm 0.02$ \\
\hline & 15 & $9.18^{\mathrm{b}} \pm 0.02$ & $9.85^{\mathrm{b}} \pm 0.03$ & $10.34^{\mathrm{c}} \pm 0.03$ \\
\hline$p$-value & & 0.050 & 0.000 & 0.000 \\
\hline \multirow[t]{4}{*}{ Streptococci } & zero & $8.99^{\mathrm{a}} \pm 0.01$ & $9.10^{\mathrm{a}} \pm 0.02$ & $9.11^{\mathrm{a}} \pm 0.04$ \\
\hline & 5 & $9.10^{\mathrm{a}} \pm 0.05$ & $9.14^{\mathrm{a}} \pm 0.03$ & $9.62^{b} \pm 0.13$ \\
\hline & 10 & $9.15^{\mathrm{a}} \pm 0.08$ & $9.62^{b} \pm 0.09$ & $9.77^{b} \pm 0.15$ \\
\hline & 15 & $9.11^{\mathrm{a}} \pm 0.02$ & $9.77^{b} \pm 0.12$ & $10.30^{c} \pm 0.05$ \\
\hline$p$-value & & 0.173 & 0.000 & 0.000 \\
\hline \multirow{4}{*}{$\begin{array}{l}\text { Total bacterial } \\
\text { counts }\end{array}$} & zero & $7.33^{\mathrm{a}} \pm 0.17$ & $7.42^{\mathrm{a}} \pm 0.16$ & $7.60^{\mathrm{a}} \pm 0.30$ \\
\hline & 5 & $7.58^{\mathrm{ab}} \pm 0.14$ & $7.74^{\mathrm{ab}} \pm 0.12$ & $7.87^{\mathrm{ab}} \pm 0.09$ \\
\hline & 10 & $7.73^{b} \pm 0.07$ & $7.96^{b} \pm 0.03$ & $8.25^{\mathrm{bc}} \pm 0.13$ \\
\hline & 15 & $7.81^{b} \pm 0.03$ & $8.05^{b} \pm 0.03$ & $8.63^{c} \pm 0.15$ \\
\hline$p$-value & & 0.050 & 0.011 & 0.019 \\
\hline \multirow[t]{4}{*}{ Mold and yeast } & zero & nil & nil & nil \\
\hline & 5 & nil & nil & nil \\
\hline & 10 & $1.17^{\mathrm{a}} \pm 0.09$ & $1.03^{\mathrm{a}} \pm 0.03$ & $1.17^{\mathrm{a}} \pm 0.09$ \\
\hline & 15 & $1.57^{b} \pm 0.18$ & $1.75^{\mathrm{b}} \pm 0.03$ & $1.75^{\mathrm{b}} \pm 0.07$ \\
\hline$p$-value & & 0.000 & 0.000 & 0.000 \\
\hline
\end{tabular}

For each stirred yoghurt sample and during the storage period (zero-15 day) the same letter means non-significant difference while a different letter means a significant difference in each microorganism by Duncan's test. The confidence level is $95 \%$. The data are expressed as mean values \pm standard error.

Control - probiotic stirred yoghurt, T1 - probiotic stirred yoghurt fortified by $1 \%$ beetroot powder, T2 - probiotic stirred yoghurt fortified by $2 \%$ beetroot powder.

samples, respectively, by the end of the storage period. was able to enhance the lactic acid bacteria counts Our obtained results indicated that beetroot powder in the stirred yoghurt and during storage. Counts of 


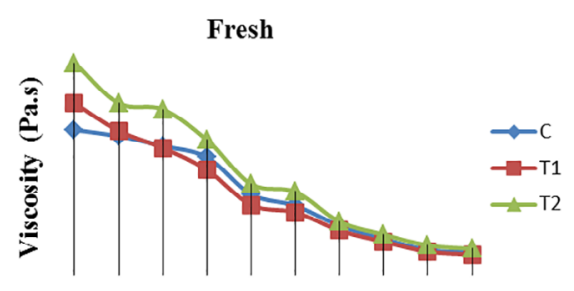

Share rate $\left(\mathbf{S}^{-1}\right)$

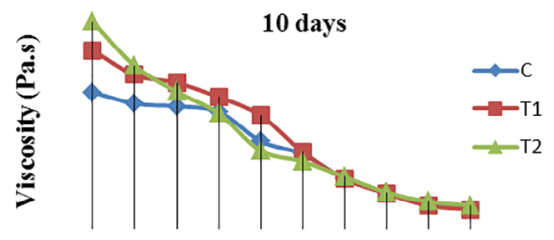

Share rate $\left(\mathbf{S}^{-1}\right)$

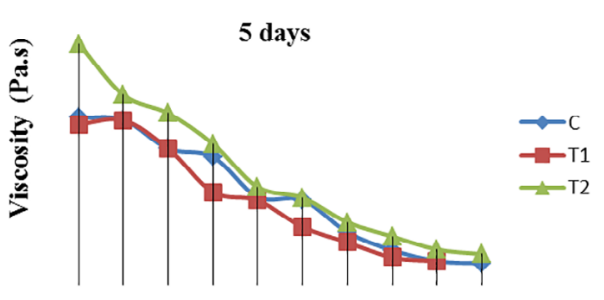

Share rate $\left(\mathbf{S}^{-1}\right)$

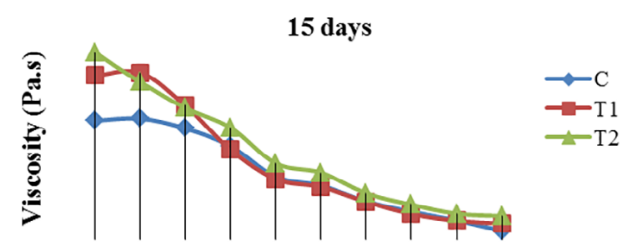

Share rate $\left(\mathbf{S}^{-1}\right)$

Fig. 4. Changes in apparent viscosity of stirred yoghurt samples during storage period at $5 \pm 2{ }^{\circ} \mathrm{C}$ for 15 days: $\mathrm{C}$ - control stirred yoghurt, $\mathrm{T} 1$ - probiotic stirred yoghurt fortified by $1 \%$ beetroot powder, T 2 - probiotic stirred yoghurt fortified by $2 \%$ beetroot powder

probiotic strains in stirred yoghurt samples were greater than $10^{7} \mathrm{CFU} / \mathrm{ml}$ during refrigerated storage. Also, Barbu et al. (2020) found that adding probiotic bacteria (Lactobacillus plantarum) to fresh beet slices increased the vitality of the cells, and this was attributed to the nutrients in the beetroot slices as lactic acid. Bacteria have easier access to beetroot nutrients (carbohydrates and proteins as sources of $\mathrm{C}$ and $\mathrm{N}$, respectively), which explains the rise in probiotic numbers.

In this work, rats were fed a high-fat diet and then injected with STZ to create a type 2 diabetes model.
To generate diabetic dyslipidemia in rats, the rats were kept on the same high-fat diet after they developed diabetes.

After one month of feeding rats a high fat diet, there was a modest rise in body weight gain, but it was not statistically significant. The total food intake recorded by rats fed on balanced diet significantly differed than those recorded by rats fed on high fat diet (Table 5). Although the amount of food consumed in the group that was fed on the diet with high-fat content was significantly less than the control group.

Table 5. Nutritional parameters after one month of the animal study (prior the injection of STZ)

\begin{tabular}{lccc}
\hline & \multicolumn{2}{c}{ Rats' groups } & \\
\cline { 2 - 3 } \multicolumn{1}{c}{ Parameters } & $\begin{array}{c}\text { normal control } \\
(n=6)\end{array}$ & $\begin{array}{c}\text { HFD } \\
(n=24)\end{array}$ & 0.694 \\
\hline Initial body weight, g & $117.33 \pm 6.18$ & $117.37 \pm 3.15$ & 0.254 \\
Final body weight, g & $188.83 \pm 10.08$ & $195.58 \pm 2.84$ & 0.273 \\
Body weight gain, g & $71.50 \pm 4.05$ & $78.21 \pm 2.29$ & 0.008 \\
Total food intake, g & $535.67 \pm 41.46$ & $460.96^{*} \pm 6.45$ & 0.652 \\
Food efficiency ratio & $0.14 \pm 0.01$ & $0.17 \pm 0.01$ & \\
\hline
\end{tabular}

*Significant at confidence interval $95 \%$.

The data are expressed as mean values \pm standard error. Data were statically analyzed by Student's $t$-test. 
The needed calories are obtained and the rest is stored in the form of fat that increases weight (Leaf and Antonio, 2017). In a previous study, rats which were fed a high-fat diet did not gain a higher weight than normal rats, but rather lipids accumulated in the liver and increased in blood resulted in fatty liver and dyslipidemia (Mohamed et al., 2019).

At the end of the animal experiment, there was a significant reduction in the final body weight and thus a significant reduction in the body weight gain of diabetic rats compared to rats fed on a balanced diet. Although a significant increase in the total food intake was recorded by diabetic rats treated with control and fortified yoghurt compared to diabetic rats fed on high-fat diet, these rats recorded body weight gain near to that recorded by diabetic rats fed on a highfat diet and significantly less than that recorded by rats fed on balanced diet (Table 6). There was no significant difference in heart weight among the groups while a significant increase in liver weight of all diabetic groups was observed compared to non-diabetic group.
As shown in Table 7, glucose, HbA1c, insulin, and IR were found to be increased significantly $(P \leq 0.05)$ in diabetic rats feeding on the high fat diet compared to normal rats. In the same manner, creatinine, urea, AST, and ALT were significantly higher in diabetic rats than in control rats. It is known that the insulin resistance is caused by a high-fat diet and in obesity which may be followed by the development of diabetes. A high-fat diet followed by low-dose streptozotocin injection causes partial destruction of beta cells in rats and thus induces hyperglycemia with inadequate insulin. The excess glucose binds by hemoglobin result in increased $\mathrm{HbAlc}$. The elevated HbAlc increases the production of oxygen radicals. Also, the excess glucose causes an increase in advanced glycated end products, which contribute to kidney damage (Rout et al., 2020). Glucose, $\mathrm{HbA} 1 \mathrm{c}$, insulin, and IR were considerably lower in diabetic rats treated with control stirred yoghurt and fortified probiotic stirred yoghurt either with $1 \%$ or $2 \%$ of beetroot powder. Treatment with control stirred yoghurt and fortified probiotic stirred yoghurt either with $1 \%$ or $2 \%$ of beetroot powder suppressed the elevation

Table 6. Nutritional parameters at the end of the animal study (two months)

\begin{tabular}{lrrrrrc}
\hline \multicolumn{1}{c}{ Parameters } & \multicolumn{7}{c}{ Rats' groups } \\
\cline { 2 - 6 } & \multicolumn{1}{c}{$\mathrm{NC}$} & $\mathrm{D}$-HFD & D-HFD $+\mathrm{CY}$ & D-HFD $+1 \% \mathrm{Y}$ & $\mathrm{D}-\mathrm{HFD}+2 \% \mathrm{Y}$ & $p$-value \\
\hline Initial body weight, g & $202.83^{\mathrm{b}} \pm 9.61$ & $175.00^{\mathrm{a}} \pm 6.42$ & $175.33^{\mathrm{a}} \pm 7.94$ & $175.00^{\mathrm{a}} \pm 4.86$ & $175.00^{\mathrm{a}} \pm 5.61$ & 0.035 \\
Final body weight, g & $251.67^{\mathrm{b}} \pm 5.76$ & $206.83^{\mathrm{a}} \pm 5.22$ & $205.83^{\mathrm{a}} \pm 8.81$ & $206.33^{\mathrm{a}} \pm 3.25$ & $204.67^{\mathrm{a}} \pm 4.73$ & 0.000 \\
Body weight gain, g & $48.83^{\mathrm{b}} \pm 5.27$ & $31.83^{\mathrm{a}} \pm 2.91$ & $30.50^{\mathrm{a}} \pm 2.43$ & $31.33^{\mathrm{a}} \pm 2.04$ & $29.67^{\mathrm{a}} \pm 2.32$ & 0.001 \\
Total food intake, g & $515.83^{\mathrm{c}} \pm 11.07$ & $436.83^{\mathrm{a}} \pm 5.64$ & $470.00^{\mathrm{b}} \pm 7.83$ & $471.50^{\mathrm{b}} \pm 6.21$ & $461.33^{\mathrm{b}} \pm 9.53$ & 0.000 \\
Food efficiency ratio & $0.10^{\mathrm{b}} \pm 0.01$ & $0.07^{\mathrm{a}} \pm 0.01$ & $0.06^{\mathrm{a}} \pm 0.01$ & $0.07^{\mathrm{a}} \pm 0.01$ & $0.06^{\mathrm{a}} \pm 0.01$ & 0.033 \\
Liver weight, g & $5.59^{\mathrm{a}} \pm 0.34$ & $6.93^{\mathrm{b}} \pm 0.30$ & $6.80^{\mathrm{b}} \pm 0.17$ & $6.65^{\mathrm{b}} \pm 0.17$ & $6.46^{\mathrm{b}} \pm 0.14$ & 0.004 \\
Liver weight, \% & $2.23^{\mathrm{a}} \pm 0.17$ & $3.37^{\mathrm{b}} \pm 0.21$ & $3.33^{\mathrm{b}} \pm 0.15$ & $3.22^{\mathrm{b}} \pm 0.06$ & $3.16^{\mathrm{b}} \pm 0.06$ & 0.000 \\
Heart weight, g & $0.71^{\mathrm{a}} \pm 0.03$ & $0.76^{\mathrm{a}} \pm 0.01$ & $0.76^{\mathrm{a}} \pm 0.03$ & $0.71^{\mathrm{a}} \pm 0.02$ & $0.70^{\mathrm{a}} \pm 0.03$ & 0.217 \\
Heart weight, $\%$ & $0.28^{\mathrm{a}} \pm 0.01$ & $0.37^{\mathrm{b}} \pm 0.01$ & $0.37^{\mathrm{b}} \pm 0.02$ & $0.35^{\mathrm{b}} \pm 0.01$ & $0.34^{\mathrm{b}} \pm 0.01$ & 0.002 \\
\hline
\end{tabular}

The same letter in each row denotes a non-significant difference, whereas a different letter denotes a significant difference by Duncan's test. The confidence level is $95 \%$. The data are expressed as mean values \pm standard error.

$\mathrm{CN}$ - control normal group, D-HFD - diabetic rats fed on high fat diet, D-HFD + CY - diabetic rats fed on high fat diet and treated with control stirred yoghurt, D-HFD $+1 \% \mathrm{Y}$ - diabetic rats fed on high fat diet and treated with probiotic stirred yoghurt fortified by $1 \%$ beetroot powder, D-HFD $+2 \% \mathrm{Y}$ - diabetic rats fed on high fat diet and treated with probiotic stirred yoghurt fortified by $2 \%$ beetroot powder. 
Mohamed, D. A., El-Sayed, H. S., Abd El-Gawad, M. A. M., Abdelgayed, S. S., Hamed, I. M., Mohamed, R. S. (2021). Characterization of stirred yoghurt enriched with probiotics and beetroot and its therapeutic potential in experimental type 2 diabetes. Acta Sci. Pol. Technol. Aliment., 20(4), 429-448. http://dx.doi.org/10.17306/J.AFS.2021.0953

Table 7. Effect of control and fortified stirred yoghurt samples on glucose, HbAlc, insulin, IR, and kidney functions

\begin{tabular}{lrrrrrc}
\hline \multirow{2}{*}{ Parameters } & \multicolumn{5}{c}{ Rats' groups } \\
\cline { 2 - 6 } & \multicolumn{1}{c}{ CN } & \multicolumn{1}{c}{ D-HFD } & D-HFD + CY & D-HFD $+1 \%$-value & D-HFD $+2 \%$ Y \\
\hline Glucose, mg/dl & $72.49^{\mathrm{a}} \pm 5.56$ & $252.13^{\mathrm{c}} \pm 7.23$ & $113.51^{\mathrm{b}} \pm 3.85$ & $101.84^{\mathrm{b}} \pm 7.71$ & $98.12^{\mathrm{b}} \pm 4.64$ & 0.000 \\
HbA1c, \% & $4.38^{\mathrm{a}} \pm 0.11$ & $7.85^{\mathrm{d}} \pm 0.08$ & $5.10^{\mathrm{c}} \pm 0.11$ & $4.90^{\mathrm{bc}} \pm 0.17$ & $4.56^{\mathrm{ab}} \pm 0.17$ & 0.000 \\
Insulin, mU/1 & $4.13^{\mathrm{a}} \pm 0.07$ & $6.62^{\mathrm{d}} \pm 0.09$ & $5.42^{\mathrm{c}} \pm 0.14$ & $5.07^{\mathrm{b}} \pm 0.08$ & $4.78^{\mathrm{b}} \pm 0.09$ & 0.000 \\
IR & $0.74^{\mathrm{a}} \pm 0.07$ & $4.12^{\mathrm{d}} \pm 0.15$ & $1.52^{\mathrm{c}} \pm 0.08$ & $1.27^{\mathrm{bc}} \pm 0.10$ & $1.15^{\mathrm{b}} \pm 0.04$ & 0.000 \\
Creatinine, mg/dl & $0.39^{\mathrm{a}} \pm 0.02$ & $0.67^{\mathrm{c}} \pm 0.04$ & $0.57^{\mathrm{bc}} \pm 0.04$ & $0.53^{\mathrm{b}} \pm 0.05$ & $0.51^{\mathrm{ab}} \pm 0.05$ & 0.002 \\
Urea, mg/dl & $24.89^{\mathrm{a}} \pm 0.63$ & $37.04^{\mathrm{c}} \pm 1.05$ & $31.12^{\mathrm{b}} \pm 1.21$ & $30.02^{\mathrm{b}} \pm 1.15$ & $29.10^{\mathrm{b}} \pm 0.60$ & 0.000 \\
AST, U/l & $43.50^{\mathrm{a}} \pm 1.33$ & $63.17^{\mathrm{c}} \pm 1.08$ & $48.00^{\mathrm{b}} \pm 0.73$ & $46.40^{\mathrm{b}} \pm 0.55$ & $46.60^{\mathrm{b}} \pm 0.42$ & 0.000 \\
ALT, U/1 & $27.17^{\mathrm{a}} \pm 0.83$ & $41.83^{\mathrm{c}} \pm 0.94$ & $32.80^{\mathrm{b}} \pm 0.87$ & $28.00^{\mathrm{a}} \pm 0.58$ & $27.20^{\mathrm{a}} \pm 0.70$ & 0.000 \\
\hline
\end{tabular}

The same letter in each row denotes a non-significant difference, whereas a different letter denotes a significant difference by Duncan's test. The confidence level is $95 \%$. The data are expressed as mean values \pm standard error.

$\mathrm{CN}$ - control normal group, D-HFD - diabetic rats fed on high fat diet, D-HFD + CY - diabetic rats fed on high fat diet and treated with control stirred yoghurt, D-HFD $+1 \% \mathrm{Y}$ - diabetic rats fed on high fat diet and treated with probiotic stirred yoghurt fortified by $1 \%$ beetroot powder, D-HFD $+2 \% \mathrm{Y}$ - diabetic rats fed on high fat diet and treated with probiotic stirred yoghurt fortified by $2 \%$ beetroot powder.

in creatinine, urea, AST, and ALT. The hypoglycemic effect of enriched yoghurt with probiotic and beetroot may be due to not only the probiotics, which have a variety of health benefits, including anti-diabetic effect and lowering cholesterol (Kocsis et al., 2020), but also to the antioxidant betalains in beetroot, which fight the radical oxidative stress via the electron denoting activity (Ninfali et al., 2017) which applies a positive effect on $\beta$-cells. This activates the insulin receptors and liberates insulin to decrease the blood glucose and accelerate the peripheral glucose utilization.

As evident from Table 8, the diabetic rats recorded significant elevations in total cholesterol, triglycerides, low-density lipoprotein cholesterol, non-HDL cholesterol, and very low low-density lipoprotein. Additionally, Ch/HDL and TG/HDL ratios considerably elevated in these rats. HDL-Ch significantly decreased in the diabetic rats compared to normal rats. The high fat diet causes dyslipidemia (Mohamed et al., 2018). The high level of trans-fatty acids in the diet raises the total cholesterol, LDL cholesterol, and triglycerides, and decreases HDL cholesterol levels. Additionally, it induces inflammation and dysregulates the endothelial function (Micha and Mozaffarian, 2008). Also, a lack of insulin leads to decreased lipoprotein lipase activity and the cholesterol ester transport protein; hence, the serum LDL-C increases, leading to type 2 diabetic dyslipidemia as reported by Taskinen and Boren (2015). Treatment with control stirred yoghurt and fortified probiotic stirred yoghurt either with $1 \%$ or $2 \%$ of beetroot powder suppressed the elevation in total cholesterol, triglycerides, low-density lipoprotein cholesterol, non-HDL cholesterol, and very low low-density lipoprotein. In addition to the positive role of enriched stirred yoghurt with probiotics in prevention of diabetic dyslipidemia and hypercholesterolemia via the inhibition of HMG-CoA reductase enzyme (Kocsis et al., 2020), the roots of beet contain several bioactive compounds, including dietary nitrate, betanin, antioxidants, polyphenols, minerals (potassium, sodium, iron, copper, magnesium, calcium, phosphorus, and zinc), and vitamins, which also play a key role in the prevention of dyslipidemia and as cardio-protective agents. In addition, the dietary fiber in beetroot reduces the concentration of blood cholesterol via elevating bile acid and short-chain fatty acid; thus promoting the proliferation of beneficial bacteria, which maximizes the benefit in reducing blood lipids (Baião et al., 2020). 
Mohamed, D. A., El-Sayed, H. S., Abd El-Gawad, M. A. M., Abdelgayed, S. S., Hamed, I. M., Mohamed, R. S. (2021). Characterization of stirred yoghurt enriched with probiotics and beetroot and its therapeutic potential in experimental type 2 diabetes. Acta Sci. Pol. Technol. Aliment., 20(4), 429-448. http://dx.doi.org/10.17306/J.AFS.2021.0953

Table 8. Effect of control and fortified stirred yoghurt samples on lipid profile

\begin{tabular}{|c|c|c|c|c|c|c|}
\hline \multirow{2}{*}{ Parameters } & \multicolumn{5}{|c|}{ Rats' groups } & \multirow{2}{*}{$p$-value } \\
\hline & $\mathrm{CN}$ & D-HFD & D-HFD + CY & $\mathrm{D}-\mathrm{HFD}+1 \% \mathrm{Y}$ & $\mathrm{D}-\mathrm{HFD}+2 \% \mathrm{Y}$ & \\
\hline T. cholesterol, mg/dl & $101.99^{\mathrm{a}} \pm 4.57$ & $246.65^{\mathrm{d}} \pm 8.13$ & $188.63^{c} \pm 13.12$ & $153.10^{\mathrm{b}} \pm 7.97$ & $135.44^{b} \pm 12.06$ & 0.000 \\
\hline $\mathrm{TG}, \mathrm{mg} / \mathrm{dl}$ & $5.52^{\mathrm{a}} \pm 0.11$ & $145.44^{c} \pm 9.34$ & $102.82^{b} \pm 4.62$ & $84.53^{\mathrm{a}} \pm 3.14$ & $80.63^{a} \pm 2.95$ & 0.000 \\
\hline $\mathrm{HDL}, \mathrm{mg} / \mathrm{dl}$ & $37.04^{\mathrm{c}} \pm 1.09$ & $26.25^{\mathrm{a}} \pm 0.84$ & $27.62^{\mathrm{a}} \pm 0.70$ & $31.04^{\mathrm{b}} \pm 0.87$ & $32.71^{\mathrm{b}} \pm 0.75$ & 0.000 \\
\hline $\mathrm{LDL}, \mathrm{mg} / \mathrm{dl}$ & $50.56^{\mathrm{a}} \pm 3.97$ & $191.30^{\mathrm{d}} \pm 7.58$ & $140.44^{\mathrm{c}} \pm 12.50$ & $105.16^{\mathrm{b}} \pm 8.18$ & $86.61^{\mathrm{b}} \pm 11.79$ & 0.000 \\
\hline Ch./HDL & $2.76^{a} \pm 0.13$ & $9.41^{\mathrm{d}} \pm 0.22$ & $6.85^{\mathrm{c}} \pm 0.51$ & $4.94^{b} \pm 0.25$ & $4.13^{b} \pm 0.33$ & 0.000 \\
\hline TG/HDL & $1.95^{\mathrm{a}} \pm 0.16$ & $5.56^{d} \pm 0.36$ & $3.73^{c} \pm 0.17$ & $2.73^{\mathrm{b}} \pm 0.11$ & $2.46^{\mathrm{ab}} \pm 0.06$ & 0.000 \\
\hline $\begin{array}{l}\text { Non-HDL cholesterol, } \\
\mathrm{mg} / \mathrm{dl}\end{array}$ & $64.95^{\mathrm{a}} \pm 4.36$ & $220.39^{d} \pm 7.52$ & $161.01^{\mathrm{c}} \pm 13.14$ & $122.06^{b} \pm 7.78$ & $102.73^{b} \pm 11.73$ & 0.000 \\
\hline VLDL, mg/dl & $14.39^{\mathrm{a}} \pm 1.10$ & $29.09^{c} \pm 1.87$ & $20.56^{\mathrm{b}} \pm 0.92$ & $16.91^{\mathrm{a}} \pm 0.63$ & $16.13^{\mathrm{a}} \pm 0.59$ & 0.000 \\
\hline
\end{tabular}

The same letter in each row denotes a non-significant difference, whereas a different letter denotes a significant difference by Duncan's test. The confidence level is $95 \%$. The data are expressed as mean values \pm standard error.

$\mathrm{CN}$ - control normal group, D-HFD - diabetic rats fed on high fat diet, D-HFD + CY - diabetic rats fed on high fat diet and treated with control stirred yoghurt, D-HFD $+1 \% \mathrm{Y}$ - diabetic rats fed on high fat diet and treated with probiotic stirred yoghurt fortified by $1 \%$ beetroot powder, D-HFD $+2 \% \mathrm{Y}$ - diabetic rats fed on high fat diet and treated with probiotic stirred yoghurt fortified by $2 \%$ beetroot powder.

Dysfunction of the thyroid gland is associated with many factors, including diabetes (Ige et al., 2019). As far as we know, studies that dealt with the effect of natural products on thyroid dysfunction associated with diabetes were little which prompted us to evaluate the role of the enriched stirred yoghurt with probiotics and beetroot in preventing thyroid dysfunction in diabetic rats. Through the results of the study (Table 9), it was confirmed that there was an increase in TSH in type 2 diabetic rats compared to non-diabetic rats. The enriched stirred yoghurt with probiotics and beetroot suppressed the elevation in TSH. This effect may be due to the probiotics that are capable of modifying the gut microbiota especially since the imbalance in the gut microbiota in diabetics is the cause of thyroid dysfunction through increasing intestinal permeability,

Table 9. Effect of control and fortified stirred yoghurt samples on TSH, CRP, and MDA

\begin{tabular}{lcccccc}
\hline \multirow{2}{*}{ Parameters } & \multicolumn{7}{c}{ Rats' groups } \\
\cline { 2 - 6 } & \multicolumn{1}{c}{ CN } & D-HFD & D-HFD + CY & D-HFD $+1 \%$ Y & D-HFD $+2 \%$-value & \\
\hline TSH, ng/ml & $0.54^{\mathrm{a}} \pm 0.04$ & $14.02^{\mathrm{d}} \pm 0.49$ & $9.05^{\mathrm{c}} \pm 0.30$ & $8.40^{\mathrm{c}} \pm 0.33$ & $6.52^{\mathrm{b}} \pm 0.18$ & 0.000 \\
$\mathrm{CRP}, \mathrm{ng} / \mathrm{ml}$ & $2.67^{\mathrm{a}} \pm 0.09$ & $5.15^{\mathrm{d}} \pm 0.18$ & $4.53^{\mathrm{c}} \pm 0.90$ & $4.17^{\mathrm{b}} \pm 0.08$ & $3.85^{\mathrm{b}} \pm 0.11$ & 0.000 \\
$\mathrm{MDA}, \mathrm{nmol} / \mathrm{ml}$ & $6.15^{\mathrm{a}} \pm 0.10$ & $11.92^{\mathrm{c}} \pm 0.43$ & $7.27^{\mathrm{b}} \pm 0.17$ & $7.03^{\mathrm{b}} \pm 0.14$ & $6.75^{\mathrm{ab}} \pm 0.13$ & 0.000 \\
\hline
\end{tabular}

The same letter in each row denotes a non-significant difference, whereas a different letter denotes a significant difference by Duncan's test. The confidence level is $95 \%$. The data are expressed as mean values \pm standard error.

$\mathrm{CN}$ - control normal group, D-HFD - diabetic rats fed on high fat diet, D-HFD + CY - diabetic rats fed on high fat diet and treated with control stirred yoghurt, D-HFD $+1 \% \mathrm{Y}$ - diabetic rats fed on high fat diet and treated with probiotic stirred yoghurt fortified by $1 \%$ beetroot powder, D-HFD $+2 \% \mathrm{Y}$ - diabetic rats fed on high fat diet and treated with probiotic stirred yoghurt fortified by $2 \%$ beetroot powder. 
and a shift to pro-inflammatory cells (Fröhlich and Wahl, 2019) and its effect on dopamine, that can inhibit TSH (Knezevic et al., 2020).

On the one hand, significant elevations in CRP and MDA were noted in diabetic rats feeding on the high fat diet compared to non-diabetic rats. On the other hand, diabetic rats treated with control stirred yoghurt and, more promisingly, fortified stirred yoghurt fortified with $2 \%$ beetroot powder, recorded CRP and MDA values significantly less than those of un-treated diabetic rats (Table 9). In addition to this, the high-fat diet promotes oxidative stress and increased inflammatory cytokines (Mohamed et al., 2020). Also, STZ injection induces oxidative stress, catalyzes the islet inflammatory cytokines and pancreatic $\beta$-cell apoptosis and decreases the antioxidant enzymes (Elfar et al., 2016). Xu et al. (2021) also found that CRP increased in type 2 diabetic rats. The antioxidant activity of enriched stirred yoghurt with beetroot might contribute to the inhibitory effect of increased MDA and CRP. Probiotic microorganisms and their biological metabolites are one of the most common exogenous antioxidant compounds. Also, the antioxidant effect of the beetroot phytochemicals may contribute to the inhibitory effect of increased MDA and CRP. Additionally, feeding rats on a high-fat diet led to a decrease in the number of beneficial bacteria (Table 10), which causes the microbial imbalance (dysbiosis) responsible for the increase in inflammation as confirmed also by Arias-Jayo et al. (2018). Thus, the dietary intervention with yoghurt containing probiotics can be attributed to reducing inflammation by modifying the gut microbiota.

The microbiota counts of rats before and after feeding on HFD changed after feeding on the highfat diet for one month (Table 10). The counts of Bifidobacterium $\mathrm{sp}$. decreased in the rats' group that were fed on HFD and this decrease was around 2.24 $\log$ cycles. But the counts of Bifidobacterium sp. in the normal rats' group was still in the same log cycle after 1 month. The same result was observed in lactobacilli counts, in which the counts of lactobacilli had declined after a month of feeding rats on HFD and reached $4.68 \log \mathrm{CFU} / \mathrm{g}$ and reached $5.31 \log \mathrm{CFU} / \mathrm{g}$ in normal rats' group. Also, the total bacterial counts changed to $6.16 \log \mathrm{CFU} / \mathrm{g}$ and $6.23 \mathrm{log} \mathrm{CFU} / \mathrm{g}$ in feeding rats on HFD and normal groups, respectively. Dissimilarly, rats feeding on the HFD were characterized by an increased relative abundance of coliform to reach $5.05 \log \mathrm{CFU} / \mathrm{g}$ in comparison with the rats' normal group, which recorded $4.48 \log \mathrm{CFU} / \mathrm{g}$.

The microbial counts of rats' feces after feeding on different stirred yoghurt samples were observed in Table 11. The counts of Bifidobacterium sp. were

Table 10. Microbial counts of rats' feces before and after feeding on the high fat diet (HFD)

\begin{tabular}{|c|c|c|c|c|}
\hline \multirow[b]{2}{*}{ Microorganisms } & \multirow{2}{*}{$\begin{array}{c}\text { Time of feeding } \\
\text { on HFD }\end{array}$} & \multicolumn{2}{|c|}{ Rats' groups } & \multirow[b]{2}{*}{$p$-value } \\
\hline & & $\begin{array}{l}\text { control normal } \\
\qquad(n=6)\end{array}$ & $\begin{array}{c}\text { HFD } \\
(n=24)\end{array}$ & \\
\hline \multirow[t]{2}{*}{ Bifidobacterium sp. } & zero & $6.74 \pm 0.10$ & $6.75 \pm 0.60$ & 0.959 \\
\hline & 1 month & $6.14 \pm 0.33$ & $4.51 * \pm 0.07$ & 0.005 \\
\hline \multirow[t]{2}{*}{ Lactobacilli } & zero & $6.72 \pm 0.16$ & $6.68 \pm 0.06$ & 0.135 \\
\hline & 1 month & $5.51 \pm 0.28$ & $4.68 * \pm 0.15$ & 0.000 \\
\hline \multirow[t]{2}{*}{ Total bacterial counts } & zero & $6.55 \pm 0.60$ & $6.66 \pm 0.70$ & 0.075 \\
\hline & 1 month & $5.31 \pm 0.28$ & $6.74 \pm 0.17$ & 0.561 \\
\hline \multirow[t]{2}{*}{ Coliforms group } & zero & $6.23 \pm 0.17$ & $6.14 \pm 0.11$ & 0.123 \\
\hline & 1 month & $4.48 \pm 0.20$ & $5.04 \pm 0.17$ & 0.372 \\
\hline
\end{tabular}

*Significant at confidence interval $95 \%$.

The data are expressed as mean values \pm standard error. Data were statically analyzed by Student's $t$-test. 
Mohamed, D. A., El-Sayed, H. S., Abd El-Gawad, M. A. M., Abdelgayed, S. S., Hamed, I. M., Mohamed, R. S. (2021). Characterization of stirred yoghurt enriched with probiotics and beetroot and its therapeutic potential in experimental type 2 diabetes. Acta Sci. Pol. Technol. Aliment., 20(4), 429-448. http://dx.doi.org/10.17306/J.AFS.2021.0953

Table 11. Microbial counts of rats' feces at the end of the experiment

\begin{tabular}{lcccccc}
\hline \multirow{2}{*}{ Microorganisms } & \multicolumn{5}{c}{ Rats' groups } \\
\cline { 2 - 6 } & $\mathrm{CN}$ & D-HFD & D-HFD + CY & D-HFD $+1 \%$ D & D-HFD $+2 \%$-value \\
\hline Bifidobacterium sp. & $5.83^{\mathrm{b}} \pm 0.31$ & $5.27^{\mathrm{a}} \pm 0.12$ & $6.92^{\mathrm{c}} \pm 0.10$ & $7.10^{\mathrm{c}} \pm 0.09$ & $7.22^{\mathrm{c}} \pm 0.13$ & 0.000 \\
Lactobacilli & $5.90^{\mathrm{a}} \pm 0.09$ & $5.52^{\mathrm{a}} \pm 0.14$ & $6.76^{\mathrm{b}} \pm 0.17$ & $6.75^{\mathrm{b}} \pm 0.19$ & $7.20^{\mathrm{b}} \pm 0.13$ & 0.000 \\
Total bacterial counts & $5.14^{\mathrm{a}} \pm 0.07$ & $5.51^{\mathrm{a}} \pm 0.15$ & $5.48^{\mathrm{a}} \pm 0.15$ & $5.36^{\mathrm{a}} \pm 0.05$ & $5.07^{\mathrm{a}} \pm 0.22$ & 0.136 \\
Coliforms group & $4.71^{\mathrm{c}} \pm 0.09$ & $5.95^{\mathrm{d}} \pm 0.19$ & $2.79^{\mathrm{a}} \pm 0.11$ & $2.98^{\mathrm{a}} \pm 0.18$ & $3.54^{\mathrm{b}} \pm 0.23$ & 0.000 \\
\hline
\end{tabular}

The same letter in each row denotes a non-significant difference, whereas a different letter denotes a significant difference by Duncan's test. The confidence level is $95 \%$. The data are expressed as mean values \pm standard error.

$\mathrm{CN}$ - control normal group, D-HFD - diabetic rats fed on high fat diet, D-HFD + CY - diabetic rats fed on high fat diet and treated with control stirred yoghurt, D-HFD $+1 \% \mathrm{Y}$ - diabetic rats fed on high fat diet and treated with probiotic stirred yoghurt fortified by $1 \%$ beetroot powder, D-HFD $+2 \% \mathrm{Y}$ - diabetic rats fed on high fat diet and treated with probiotic stirred yoghurt fortified by $2 \%$ beetroot powder.

increased in the rats' feces that feeding on stirred yoghurt fortified with beetroot and probiotic strains. The counts of Bifidobacterium sp. were recorded $6.92 \mathrm{log}$ $\mathrm{CFU} / \mathrm{g}$ in feeding group on traditional stirred yoghurt and recorded 7.10 and $7.22 \mathrm{log} \mathrm{CFU} / \mathrm{g}$ in feeding groups on stirred yoghurt with $1 \%$ and $2 \%$ beetroot and probiotic strains, respectively. But the Bifidobacterium sp. counts were less in normal and diabetic groups, which recorded 5.83 and $5.27 \log \mathrm{CFU} / \mathrm{g}$, respectively. The same trend of results was observed for lactobacilli. The high counts of lactobacilli in rats' feces after feeding were recorded for group feeding on stirred yoghurt fortified with $1 \%$ and $2 \%$ beetroot with probiotic strains compared with normal and diabetic groups. The lactobacilli counts were recorded 6.76, 6.75 , and $7.20 \log \mathrm{CFU} / \mathrm{g}$ in rats' groups feeding on traditional stirred yoghurt, stirred yoghurt contained probiotic strains and $1 \%$ and $2 \%$ beetroot, respectively. Moreover, our results did not indicate a significant difference in the total bacterial counts in all the rats' feces groups after feeding. The total microbial counts were recorded in 5 log cycles in all the groups. In comparison, the high count of coliforms were recorded in the diabetic rats' group, which reached to $5.95 \mathrm{log}$ $\mathrm{CFU} / \mathrm{g}$, followed with rats in normal group (4.71 log $\mathrm{CFU} / \mathrm{g}$ ). Low numbers of coliforms were recorded for rats' groups feeding on stirred yoghurt fortified with $1 \%$ and $2 \%$ beetroot with probiotic strains (2.98 and $2.79 \log \mathrm{CFU} / \mathrm{g}$, respectively). Our results indicated that the feeding rats on stirred yoghurt supplemented with beetroot and probiotic strains enhanced the microbiotia of rats.

Histopathological findings of liver sections (Fig. 5) illustrated the normal structure of the control rats' liver which was formed from polygonal lobules, whilst the outlines of the lobules were indistinct. Hepatocytes were polyhedral in shape, had vesicular spherical nuclei with prominent nucleoli and eosinophilic cytoplasm. Hepatocytes were arranged in cords that radiated out from the center of each lobule where the central vein situated and between these hepatic cords were the hepatic sinusoids which are localized in between the cords and contained a fine arrangement of Kupffer cells (Fig. 5a). The diabetic rats revealed massive diffuse fatty degeneration in the form of round circumscribed round vacuolated hepatocytes with peripheral nuclei in the form of signet ring appearance. Moreover there were marked portal tract changes in the form of congestion in the hepatoportal blood vessel and mononuclear cells infiltration (Fig. 5b). Diabetic rats fed on the high-fat diet and treated with control stirred yoghurt denoted regression in the distribution of fatty degeneration compared to that of the control group to become a multifocal diffuse pattern - there was no congestion or mononuclear cells infiltration (Fig. 5c). Diabetic rats fed on the high-fat diet and treated with probiotic stirred yoghurt fortified by $1 \%$ beetroot powder revealed mild focal distribution of fatty degeneration without congestion or mononuclear cells infiltration (Fig. 5d). 
Mohamed, D. A., El-Sayed, H. S., Abd El-Gawad, M. A. M., Abdelgayed, S. S., Hamed, I. M., Mohamed, R. S. (2021). Characterization of stirred yoghurt enriched with probiotics and beetroot and its therapeutic potential in experimental type 2 diabetes. Acta Sci. Pol. Technol. Aliment., 20(4), 429-448. http://dx.doi.org/10.17306/J.AFS.2021.0953
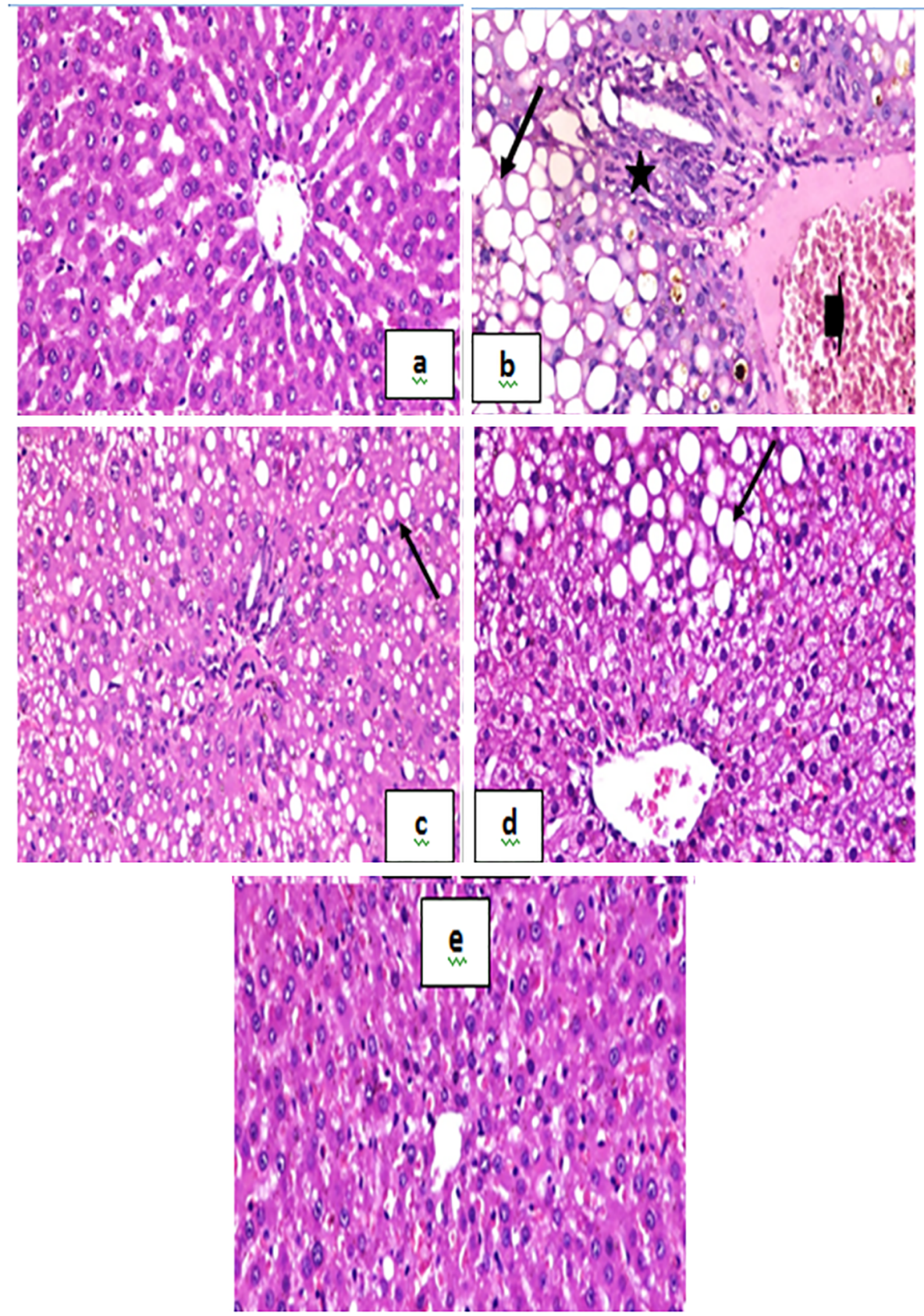

Fig. 5. Liver sections of different groups. a - control normal group: note the normal hepatocytes, blood sinusoids, central vein, and portal tract; $\mathbf{b}$ - diabetic rats fed on high fat diet: note the massive diffuse fatty degenerated hepatocytes (arrow), hepatoportal blood vessel congestion (arrow head), and mononuclear cells infiltration (star); c - diabetic rats fed on high fat diet and treated with control stirred yoghurt: note the multifocal diffuse fatty degenerated hepatocytes (arrow), no congestion no mononuclear cells infiltration; $\mathbf{d}$ - diabetic rats fed on high fat diet and treated with probiotic stirred yoghurt fortified by $1 \%$ beetroot powder: note the focal fatty degenerated hepatocytes (arrow), no congestion no mononuclear cells infiltration; e - diabetic rats fed on high fat diet and treated with probiotic stirred yoghurt fortified by $2 \%$ beetroot powder: note the normal hepatocytes, blood sinusoids, central vein, and portal tract (H\&E X 400) 
Mohamed, D. A., El-Sayed, H. S., Abd El-Gawad, M. A. M., Abdelgayed, S. S., Hamed, I. M., Mohamed, R. S. (2021). Characterization of stirred yoghurt enriched with probiotics and beetroot and its therapeutic potential in experimental type 2 diabetes. Acta Sci. Pol. Technol. Aliment., 20(4), 429-448. http://dx.doi.org/10.17306/J.AFS.2021.0953
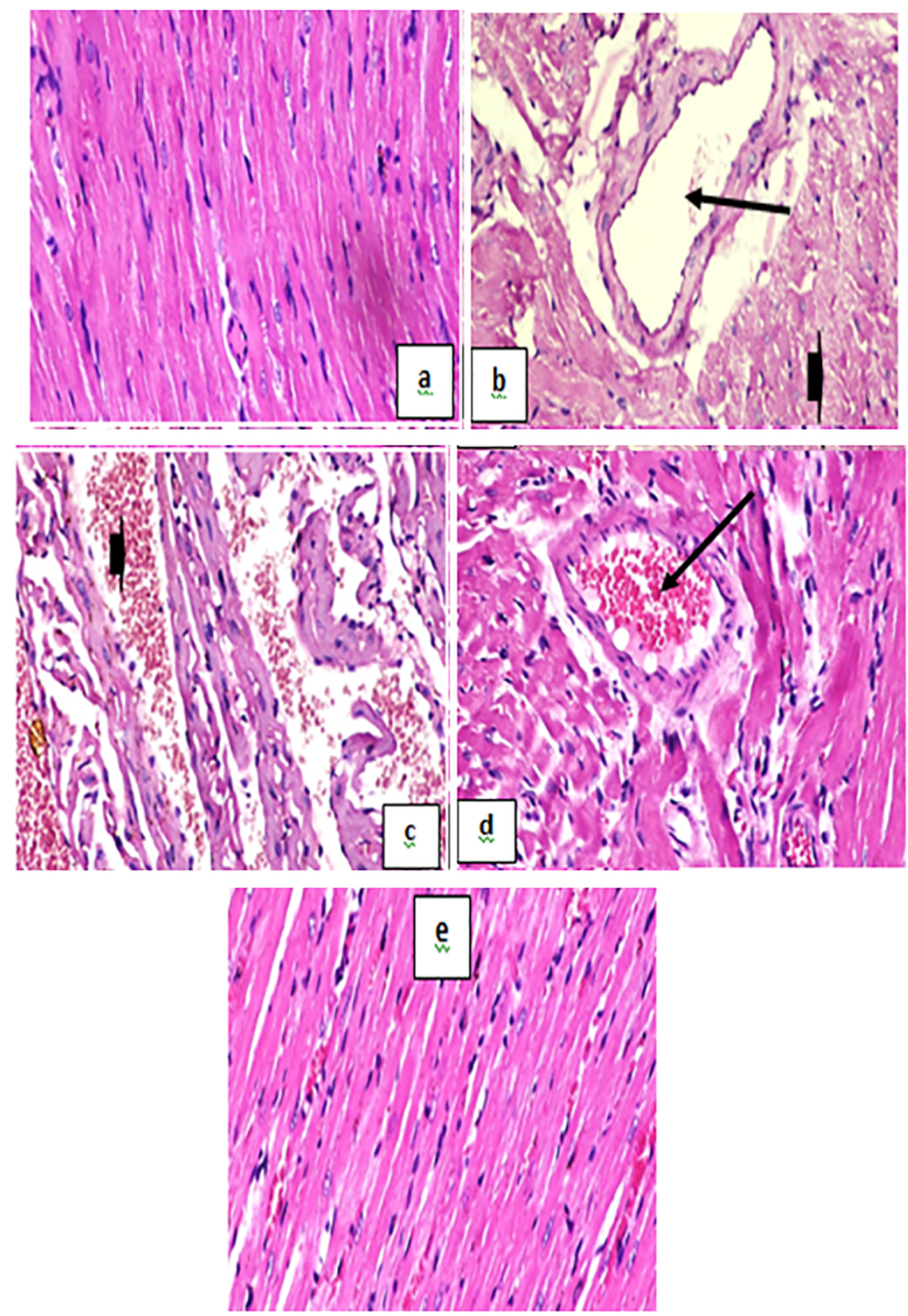

Fig. 6. Heart sections of different groups. a - control normal group: note the normal muscle fibers, striation, and nucleation; b - diabetic rats fed on high fat diet: note the massive diffuse hyalinosis and Zinker's necrosis of myocardial muscle fibers (arrow head), and blood vessel dilatation (arrow) and congestion; c - diabetic rats fed on high fat diet and treated with control stirred yoghurt: note the focal areas of hemorrhages (arrow head), no hyalinosis and Zinker's necrosis of myocardial muscle fibers; $\mathbf{d}$ - diabetic rats fed on high fat diet and treated with probiotic stirred yoghurt fortified by $1 \%$ beetroot powder: note the congestion of blood vessel (arrow), no hyalinosis and Zinker's necrosis of myocardial muscle fibers; $\mathbf{e}$ - diabetic rats fed on high fat diet and treated with probiotic stirred yoghurt fortified by $2 \%$ beetroot powder: note the normal muscle fibers, striation, and nucleation (H\&E X 400) 
The diabetic rats which fed on the high-fat diet and were treated with probiotic stirred yoghurt fortified by $2 \%$ beetroot powder revealed normal histological lesions similar to those of the control negative group (Fig. 5e).

Histopathological findings of heart sections (Fig. 6) illustrated the normal structure of control rats' heart which was formed from normal muscle fibers, striation, and nucleation (Fig. 6a). Diabetic rats revealed massive diffuse hyalinosis and Zinker's necrosis of myocardial muscle fibers which lose its normal structure, striation, and nucleation, together with blood vessel dilatation and congestion (Fig. 6b). Diabetic rats fed on high fat diet and treated with control stirred yoghurt denoted focal areas of hemorrhages without hyalinosis or Zinker's necrosis of myocardial muscle fibers unlike that of the control positive group (Fig. 5c). Diabetic rats fed on the high-fat diet and treated with probiotic stirred yoghurt fortified by $1 \%$ beetroot powder revealed normal muscle fibers, striation, and nucleation with mild congestion of the blood vessel (Fig. 6d). Diabetic rats fed on the high-fat diet and treated with probiotic stirred yoghurt fortified by $2 \%$ beetroot powder revealed normal histological lesions similar to those of the control normal group (Fig. 6e).

\section{CONCLUSION}

The stirred yoghurt enriched with probiotics and beetroot showed antioxidant activity, recorded high sensorial scores, and increased counts of bifidobacterium and lactobacilli either in the stirred yoghurt over the storage period or in the feces of rats. Also, the stirred yoghurt enriched with probiotics and beetroot exhibited a hypoglycemic effect, improved the lipid profile, and suppressed the elevation in CRP, MDA, and TSH. Histopathologically, the fatty cells in liver tissues were eliminated after the intervention with probiotic stirred yoghurt fortified with $2 \%$ beetroot. Also, the heart tissue of rats treated with probiotic stirred yoghurt fortified with $2 \%$ beetroot seemed like normal heart tissue. Thus, the stirred yoghurt enriched with probiotics and beetroot has therapeutic potential for type 2 diabetes that evidenced in the high-fat diet-fed and streptozotocin-treated rats.

\section{REFERENCES}

Arias-Jayo, N., Abecia, L., Alonso-Sáez, L., Ramirez-Garcia, A., Rodriguez, A., Pardo, M. A. (2018). High-fat diet consumption induces microbiota dysbiosis and intestinal inflammation in zebrafish. Microb. Ecol., 76(4), 1089-1101. https://doi.org/10.1007/s00248-018-1198-9

Arslan, S., Ozel, S. (2012). Some properties of stirred yoghurt made with processed grape seed powder, carrot juice or a mixture of grape seed powder and carrot juice. Milchwiss.-Milk Sci. Int., 67, 281-285.

Baião, D. D. S., da Silva, D. V., Paschoalin, V. M. (2020). Beetroot, a remarkable vegetable: Its nitrate and phytochemical contents can be adjusted in novel formulations to benefit health and support cardiovascular disease therapies. Antioxidants, 9(10), 960. https://doi.org/10.3390/ antiox9100960

Barbu, V., Cotârleț, M., Bolea, C. A., Cantaragiu, A., Andronoiu, D. G., Bahrim, G. E., Enachi, E. (2020). Three types of beetroot products enriched with lactic acid bacteria. Foods, 9(6), 786. https://doi.org/10.3390/foods 9060786

Bommer, C., Sagalova, V., Heesemann, E., Manne-Goehler, J., Atun, R., Bärnighausen, T., ..., Vollmer, S. (2018). Global economic burden of diabetes in adults: projections from 2015 to 2030. Diab. Care, 41, 963-970. https://doi.org/10.2337/dc17-1962

Chang, C. C., Yang, M. H., Wen, H. M., Chern, J. C. (2002). Estimation of total flavonoid content in propolis by two complementary colorimetric methods. J. Food Drug Anal., 10, 178-182.

Elfar, Y. M., Zakaria, M. M., Gabr, M. M., El-Gayar, A. M., El-Sherbiny, I. M., Eissa, L.A. (2016). Anewly developed silymarin nanoformulation as a potential antidiabetic agent in experimental diabetes. Nanomedicine, 11(19), 2581-2602. https://doi.org/10.2217/nnm-2016-0204

Fröhlich, E., Wahl, R. (2019). Microbiota and thyroid interaction in health and disease. Trends Endocrinol. Metab., 30(8), 479-490. https://doi.org/10.1016/j.tem.2019. 05.008

Ige, A. O., Chidi, R. N., Egbeluya, E. E., Jubreel, R. O., Adele, B. O., Adewoye, E. O. (2019). Amelioration of thyroid dysfunction by magnesium in experimental diabetes may also prevent diabetes-induced renal impairment. Heliyon, 5(5), e01660. https://doi.org/10.1016/j. heliyon.2019.e01660

Jin, R. C., Loscalzo, J. (2010). Vascular nitric oxide: formation and function. J. Blood Med., 2010, 147-162. https:// doi.org/10.2147/jbm.s7000 
Mohamed, D. A., El-Sayed, H. S., Abd El-Gawad, M. A. M., Abdelgayed, S. S., Hamed, I. M., Mohamed, R. S. (2021). Characterization of stirred yoghurt enriched with probiotics and beetroot and its therapeutic potential in experimental type 2 diabetes. Acta Sci. Pol. Technol. Aliment., 20(4), 429-448. http://dx.doi.org/10.17306/J.AFS.2021.0953

Knezevic, J., Starchl, C., Tmava Berisha, A., Amrein, K. (2020). Thyroid-gut-axis: How does the microbiota influence thyroid function? Nutrients, 12(6), 1769. https:// doi.org/10.3390/nu12061769

Kocsis, T., Molnár, B., Németh, D., Hegyi, P., Szakács, Z., Bálint, A., ..., Solymár, M. (2020). Probiotics have beneficial metabolic effects in patients with type 2 diabetes mellitus: a meta-analysis of randomized clinical trials. Sci. Rep., 10(1), 1-14. https://doi.org/10.1038/s41598020-68440-1

Larsen, N., Vogensen, F. K., Van Den Berg, F. W., Nielsen, D. S., Andreasen, A. S., Pedersen, B. K., ..., Jakobsen, M. (2010). Gut microbiota in human adults with type 2 diabetes differs from non-diabetic adults. PloS One, 5(2), e9085. https://doi.org/10.1371/journal.pone.0009085

Leaf, A., Antonio, J. (2017). The effects of overfeeding on body composition: The role of macronutrient composition - A narrative review. Int. J. Exerc. Sci., 10(8), 1275-1296.

Lidder, S., Webb, A. J. (2013). Vascular effects of dietary nitrate (as found in green leafy vegetables and beetroot) via the nitrate-nitrite-nitric oxide pathway. Br. J. Clin. Pharmacol., 75(3), 677-696. https://doi.org/10.1111/ j.1365-2125.2012.04420.x

Ling, E. R. (1963). A textbook of dairy chemistry. Vol. 2. Practical. London: Chapman and Hall.

Micha, R., Mozaffarian, D. (2008). Trans fatty acids: Effects on cardiometabolic health and implications for policy. Prostagl. Leukot. Essent. Fat. Acids, 79, 147-152. https://doi.org/10.1016/j.plefa.2008.09.008

Mohamed, D. A., Abdelgayed, S. S., Essa, H. A., Mohamed, R. S. (2018). Preparation and evaluation of functional foods for prevention of non-alcoholic fatty liver disease. Pak. J. Biol. Sci., 21(9), 454-462. https://doi. org/10.3923/pjbs.2018.454.462

Mohamed, D. A., Fouda, K. A., Mohamed, R. S. (2019). In vitro anticancer activity of quinoa and safflower seeds and their preventive effects on non-alcoholic fatty liver. Pak. J. Biol. Sci., 22(8), 383-392. https://doi.org/ 10.3923/pjbs.2019.383.392

Mohamed, D. A., Mohamed, R. S., Fouda, K. (2020). Anti-inflammatory potential of chia seeds oil and mucilage against adjuvant-induced arthritis in obese and non-obese rats. J. Basic Clin. Physiol. Pharmacol., 1, 20190236. https://doi.org/10.1515/jbcpp-2019-0236

Ninfali, P., Antonini, E., Frati, A., Scarpa, E. S. (2017). C-Glycosyl flavonoids from Beta vulgaris cicla and betalains from Beta vulgaris rubra: antioxidant, anticancer and antiinflammatory activities - A review. Phytother. Res., 31(6), 871-884. https://doi.org/10.1002/ptr.5819
Ranjith, K. K., Xiao-Fen, L., Hu-Fan, S., Shi-Bin, W., Da-Yun, Y., Yu, S. Z., Ai-Zheng, C. (2018). Supercritical fluid-assisted decoration of nanoparticles on porous microcontainers for codelivery of therapeutics and inhalation therapy of diabetes. ACS Biomater. Sci. Eng., 4(12), 4225-4235. https://doi.org/10.1021/ acsbiomaterials. 8 b00992

Reeves, P. G., Nielsen, F. H., Fahey, G. C. (1993). AIN-93 purified diets for laboratory rodents: Final report of the American Institute of Nutrition Ad Hoc Writing Committee on the reformulation of the AIN-76A rodent diet. J. Nutr., 123, 1939-1951. https://doi.org/10.1093/ jn/123.11.1939

Rout, D., Dash, U. C., Kanhar, S., Swain, S. K., Sahoo, A. K. (2020). The modulatory role of prime identified compounds in the bioactive fraction of Homalium zeylanicum in high-fat diet fed-streptozotocin-induced type 2 diabetic rats. J. Ethnopharmacol., 260, 113099. https:// doi.org/10.1016/j.jep.2020.113099

Singleton, V. L., Orthofer, R., Lamuela-Ravento's, R. M. (1999). Analysis of total phenols and other oxidation substrates and antioxidants by means of Folin-Ciocalteu reagent. Method. Enzymol., 299, 152-178. https://doi. org/10.1016/s0076-6879(99)99017-1

Srinivasan, K., Viswanad, B., Asrat, L., Kaul, C. L., Ramarao, P. (2005). Combination of high-fat diet-fed and low-dose streptozotocin-treated rat: a model for type 2 diabetes and pharmacological screening. Pharmacol. Res., 52(4), 313-320. https://doi.org/10.1016/j. phrs.2005.05.004

Taskinen, M. R., Boren, J. (2015). New insights into the pathophysiology of dyslipidaemiain type 2 diabetes. Atherosclerosis, 239(2), 483-495. https://doi.org/10. 1016/j.atherosclerosis.2015.01.039

Wang, C., Zhang, C., Li, S., Yu, L., Tian, F., Zhao, J., ..., Zhai, Q. (2020). Effects of probiotic supplementation on dyslipidemia in type 2 diabetes mellitus: A meta-analysis of randomized controlled trials. Foods, 9(11), 1540 . https://doi.org/10.3390/foods9111540

Xu, J., Fu, C., Li, T., Xia, X., Zhang, H., Wang, X., Zhao, Y. (2021). Protective effect of acorn (Quercus liaotungensis Koidz) on streptozotocin-damaged MIN6 cells and type 2 diabetic rats via p38 MAPK/Nrf2/HO-1 pathway. J. Ethnopharmacol., 266, 113444.] https://doi. org/10.1016/j.jep.2020.113444

Zhu, Z., Lin, Z., Jiang, H., Jiang, Y., Zhao, M., Liu, X. (2017). Hypolipidemic effect of Youcha in hyperlipidemia rats induced by high-fat diet. Food Funct., 8(4), 1680-1687. https://doi.org/10.1039/c7fo00089h 